\title{
Gene expression analyses of primary melanomas reveal CTHRC1 as an important player in melanoma progression
}

\author{
Johanna Eriksson ${ }^{1}$, Vadim Le Joncour ${ }^{2}$, Pirjo Nummela ${ }^{1}$, Tiina Jahkola ${ }^{3}$, Susanna \\ Virolainen ${ }^{1}$, Pirjo Laakkonen ${ }^{2}$, Olli Saksela ${ }^{4}$, Erkki Hölttä ${ }^{1}$ \\ ${ }^{1}$ Department of Pathology, University of Helsinki, FI-00014 Helsinki, Finland \\ ${ }^{2}$ University of Helsinki, Research Programs Unit, Translational Cancer Biology, Biomedicum Helsinki, FI-00014 Helsinki, \\ Finland \\ ${ }^{3}$ Department of Plastic Surgery, Helsinki University Central Hospital, FI-00029 Helsinki, Finland \\ ${ }^{4}$ Department of Dermatology, Helsinki University Central Hospital, FI-00029 Helsinki, Finland \\ Correspondence to: Erkki Hölttä, e-mail: erkki.holtta@helsinki.fi
}

Keywords: melanoma, invasion/metastasis, CTHRC1, NFATC2, TGF $\beta$

Received: June 11,2015 Accepted: January 31,2016 Published: February 23, 2016

\section{ABSTRACT}

Melanoma is notorious for its high tendency to metastasize and its refractoriness to conventional treatments after metastasis, and the responses to most targeted therapies are short-lived. A better understanding of the molecular mechanisms behind melanoma development and progression is needed to develop more effective therapies and to identify new markers to predict disease behavior. Here, we compared the gene expression profiles of benign nevi, and non-metastatic and metastatic primary melanomas to identify any common changes in disease progression. We identified several genes associated with inflammation, angiogenesis, and extracellular matrix modification to be upregulated in metastatic melanomas. We selected one of these genes, collagen triple helix repeat containing 1 (CTHRC1), for detailed analysis, and found that CTHRC1 was expressed in both melanoma cells and the associated fibroblasts, as well as in the endothelium of tumor blood vessels. Knockdown of CTHRC1 expression by shRNAs in melanoma cells inhibited their migration in Transwell assays and their invasion in three-dimensional collagen and Matrigel matrices. We also elucidated the possible down-stream effectors of CTHRC1 by gene expression profiling of the CTHRC1-knockdown cells. Our analyses showed that CTHRC1 is regulated coordinately with fibronectin and integrin $\beta 3$ by the pro-invasive and -angiogenic transcription factor NFATC2. We also found CTHRC1 to be a target of TFG $\beta$ and BRAF. These data highlight the importance of tumor stroma in melanoma progression. Furthermore, CTHRC1 was recognized as an important mediator of melanoma cell migration and invasion, providing together with its regulators-NFATC2, TGF $\beta$, and BRAF-attractive therapeutic targets against metastatic melanomas.

\section{INTRODUCTION}

Cutaneous melanoma represents one of the most aggressive malignancies, with a high tendency to metastasize. Melanoma may develop directly from transformed melanocytes/melanocyte precursor cells or through a stepwise progression first forming a benign nevus [1]. The nevus cells may acquire dysplastic features through genetic changes and further develop into a radial growth phase primary melanoma, which usually grows horizontally and rarely metastasizes. Through additional genetic and epigenetic changes, a vertical growth phase (VGP) primary melanoma may form, carrying an increased risk for metastasis. A vast number of mutations, including those of TERT, BRAF, NRAS, PTEN, and CDKN2A, have been linked to the malignant transformation of melanocytes in subgroups of primary melanomas [2-4], rendering therapeutic approaches challenging. A better strategy might, therefore, consist of identifying possible molecular changes common to the development and 
progression of different primary melanoma subtypes, which could be targeted together with the oncogenic driver mutations.

The Breslow's thickness [5] of the primary tumor is considered the best independent prognostic indicator in melanoma and the most important factor in assessing the risk of developing metastatic disease [6]. However, a significant portion $(6.7 \%)$ of patients with thin melanomas (Breslow's thickness of $0.51-1.0 \mathrm{~mm}$ ) present with disseminated disease [7], and 3\% to $6 \%$ of patients with primary melanomas $<1 \mathrm{~mm}$ thickness die of their disease within five years of diagnosis [6]. These cases show that the metastatic potential of primary melanomas may not be predicted from the morphological features alone and the use of routine histologic prognostic factors is insufficient for melanoma staging. In recent years, lymphatic mapping with invasive sentinel lymph node biopsy has become the standard staging method for melanoma, and the status of the sentinel lymph nodes represents a strong predictor of survival [8]. However, a portion of patients with metastatic disease remains undetected by this method, since $6 \%$ to $17 \%$ of sentinel lymph node - negative patients die within five years of diagnosis [8], indicating the presence of false-negative results or an alternative route of metastasis, i.e., hematogenous spreading. The shortcomings of these prognostic factors are indicative of the urgent need for new, better markers capable of identifying (preferably already in the primary tumors) the features determining the course of disease. This would spare patients from unnecessary surgery and morbidity related to sentinel lymph node biopsy. Unraveling the molecular events related to melanoma progression should also provide rational targets for novel therapeutic approaches. This is particularly important given that metastatic melanoma remains extremely difficult to cure. Recently, new molecularly targeted therapies against metastatic melanoma have been developed, but the responses have thus far remained transient and incomplete [2], whereby survival rates for patients with distant metastases have not improved much [6,9].

Herein, our approach to reveal the molecular mechanisms underlying the development and progression of melanomas was to compare the gene expression profiles of benign nevi, and non-metastatic and metastatic primary melanomas. In particular, we aimed to identify possible changes common to all primary melanomas and, since the tumor microenvironment is known to promote tumor development and progression, also to identify the gene expression changes occurring in the tumor stroma. We found several genes associated with inflammation, angiogenesis, and extracellular matrix (ECM) modification to be commonly upregulated during the development and spreading of melanoma. Of particular interest, we found that the collagen triple helix repeat containing 1 (CTHRC1) gene was overexpressed in metastatic primary melanomas, and a high expression of CTHRC1
mRNA was associated with a short survival. We found that CTHRC1 was expressed by melanoma cells, activated stromal fibroblasts, and blood vessel endothelial cells. Our functional analyses suggested that CTHRC 1 is required for the migration and invasion of melanoma cells in vitro, and that it may participate in regulating the switch between proliferation and invasion in vivo. Further, we found that the expression of CTHRC1 is induced coordinately with fibronectin (FN1) and integrin $\beta 3$ (ITGB3) by the proinvasive and -angiogenic transcription factor NFATC2 (the nuclear factor of activated T-cells, cytoplasmic, calcineurin-dependent 2). In addition to NFATC2, we found that CTHRC1 expression was increased by TGF $\beta$ and oncogenic BRAF signaling, making CTHRC1 an attractive new target for therapy.

\section{RESULTS}

\section{Microarray analysis of benign nevi and primary melanomas}

We first sought to identify those genes involved in melanoma development by comparing the gene expression profiles of fresh or frozen benign nevus $(n=11)$ and primary melanoma tissue samples $(n=21)$ also containing the adjacent stromal compartment. We were particularly interested in finding any common changes accompanying the development of heterogeneous primary melanomas. Significance Analysis of Microarrays (SAM) identified 1547 probe sets representing 1058 genes overexpressed $\geq 1.5$-fold (Supplementary Table S1) and 1042 probe sets representing 731 genes underexpressed $\geq 1.5$-fold (Supplementary Table S2) in primary melanomas compared to benign nevi. To determine which processes and pathways are activated in primary melanomas, we aimed to identify Gene Ontology (GO) classes and KEGG pathways overrepresented in the gene list and found, among others, inflammatory response (GO:0006954, $P=5.7 \times 10^{-7}$, associated with, for instance, chemokine receptor $C X C R 4$, TGFB1, S100A8, and S100A9), blood vessel development (GO:0001568, $P=3.5 \times 10^{-6}$, associated with THY1, COL4A2, CYR61, and FN1), cell motility (GO:0048870, $P=6.6 \times 10^{-6}$, associated with CTHRC1, VCAN, THBS1, $P L A U$, and ITGB2), and ECM-receptor interaction (KEGG:04512, $P=2.0 \times 10^{-6}$, associated with collagens, $T N C, F N 1, C D 36$, laminins, and thrombospondins) as highly significant biological processes enriched among the overexpressed genes. To identify possible markers differentiating between benign nevi and melanoma, we filtered the gene list for at least a fourfold difference in the mean expression levels between groups (shown in bold in Supplementary Table S1). Here, genes encoding S100A proteins (S100A7, S100A8, and S100A9), MIR21, CTHRC1, $C X C R 4, R G S 1, P R A M E$, and SPP1 were identified as particularly interesting potential melanoma or melanomaassociated markers. Based on our microarray analyses of 
primary melanoma cells and melanoma cell lines as well as the publicly available microarray data of melanoma cell lines ( $n=34$; E-GEOD-7152), all of these potential markers except the S100A proteins may be expressed by melanoma cells (data not shown).

We then compared the gene expression profiles of non-metastatic and metastatic primary melanomas to determine which genes are involved in the metastatic process and the progression of melanomas, and to identify the potential predictive markers for metastasis. We followed patients in the non-metastatic group for 53 to 90 months (median follow-up, 84.5 months) with no signs of disease progression, while all patients in the metastatic group developed metastases within 0 to 9 months (median, 0 months) after the primary melanoma excision. SAM resulted in 1050 probe sets representing 787 genes overexpressed $\geq 1$.5-fold (Supplementary Table S3) and 1517 probe sets representing 1133 genes underexpressed $\geq 1.5$-fold (Supplementary Table S4) in the metastatic primary melanomas. A query of the SAM-ordered probes using the Gene Set Enrichment Analysis (GSEA) tool revealed that genes involved in the epithelialmesenchymal transition (a gene set in the Hallmark signatures collection of the Molecular Signature Database) were enriched among those genes overexpressed in the metastatic primary melanomas (normalized enrichment score of 3.96 and false discovery rate q-value of $<0.001)$. Further, genes associated with cell adhesion (GO:0007155, $P=6.9 \times 10^{-10}$, e.g., VCAN, SPP1, FN1, NEDD9, and ITGB3), locomotion (GO:0040011, $P=2.5 \times 10^{-9}$, TIMP1, $V C A N, T N S 3$, and $C T H R C 1$ ), and vasculature development (GO:0001944, $P=3.4 \times 10^{-8}$, ITGA5, COL4A1, THY1, $F N 1$, and $C Y R 61$ ) were upregulated in metastatic primary melanomas. Among the most interesting, highly and significantly over-expressed genes in metastatic primary melanomas were TIMP1, VCAN, SPP1, and CTHRC1, all of which are expressed both by stromal fibroblasts and melanoma cells (data not shown).

To determine if any genes were related to both the development and progression of melanomas, we analyzed the above gene lists for common genes (Table 1). In addition to the four genes mentioned above, we found that many of the top genes encode proteins that reside within or modify the extracellular space/proteinaceous ECM or function in cell adhesion, migration, invasion, or angiogenesis, such as SERPINH1 [10], LGALS1 [11], SULF1 [12], COL4A1 [13], THY1 [14], MME [15], LOXL2 [16], and ADAM12 [17]. In addition, we found that the transcription factor HEY1 was commonly upregulated. We also searched the gene expression profiles of primary melanomas for potential markers of poor prognosis using the SAM survival analysis. We identified several interesting candidate genes, which were also specifically upregulated in melanoma cells compared to normal melanocytes. Of these genes, FN1, P4HA1, RHOC, $S C R G 1, S 100 B$, and SERPINA3 were most significantly associated with a short survival (Table 2). Noteworthy, several genes with a prognostic value, including FN1 and $P 4 H A 1$, are known to be induced by hypoxia $[18,19] . F N 1$ is also one of the genes overexpressed both in primary melanomas compared to benign nevi (2.2-fold) and in metastatic compared to non-metastatic primary melanomas (2.0-fold) (Table 1). We further compared the Kaplan-Meier survival rates of patients with primary melanomas showing low and high FN1 mRNA expression levels and found the survival times to differ highly significantly between patient groups (Supplementary Figure S1A).

\section{CTHRC1 expression in different cell types}

CTHRC1 is another interesting gene significantly overexpressed in primary melanomas compared to benign nevi (4.1-fold) and in metastatic compared to non-metastatic primary melanomas (2.4-fold) (Table 1). We confirmed the overexpression of CTHRC1 mRNA in primary melanomas compared to benign nevi using quantitative RT-PCR (qRT-PCR) in a subset of the microarray samples (Breslow's thickness: mean $=10.6$ $\mathrm{mm}$, median $=6.7 \mathrm{~mm}$ ) as well as in an independent sample set (Breslow's thickness: mean $=4.1 \mathrm{~mm}$, median $=4.0 \mathrm{~mm}$ ), finding 11.8-fold and 4.7-fold differences, respectively, in the expression levels between groups (Figure 1A). Since we found that CTHRC1 was further overexpressed in metastatic primary melanomas, we sought to determine if CTHRC1 expression was associated with patient survival. Despite the limited sample size, we found a significant association between a shorter survival time and a high CTHRC1 mRNA expression in primary melanomas (Supplementary Figure S1B).

To determine which cell types are responsible for producing CTHRC1 in melanoma, we first used qRT-PCR to analyze the expression levels of CTHRC1 mRNA in primary human melanocytes, benign nevus cells, and melanoma cells isolated from primary tumors and lymph node metastases, as well as in primary human fibroblasts and endothelial cells. Among the primary cells, we found that both embryonic and adult skin fibroblasts showed the highest expression of CTHRC1 (Figure 1B). The cells from primary and metastatic melanomas showed a variable but higher (46-fold) CTHRC1 expression than normal melanocytes or benign nevus cells, in which CTHRC1 expression was virtually absent. The microvascular endothelial cells, in turn, expressed CTHRC1 mRNA at a moderate level similar to the melanoma cells. Our analyses of the established melanoma cell lines from VGP primary melanomas (WM115 and WM793) and melanoma metastases (WM239, MM170, SKMEL-28, SKMEL-103, SKMEL-147, and BLM) revealed that they expressed variable levels of CTHRC1 mRNA. The metastatic MM170 and SKMEL-28, as well as the VGP WM115 and metastatic WM239 melanoma cell lines 
Table 1: The most significantly over-expressed genes ${ }^{a}$ shared in comparisons of primary melanomas vs benign nevi and metastatic vs non-metastatic primary melanomas by Significance Analysis of Microarrays (SAM) (ordered by SAM score of metastatic vs non-metastatic primary melanomas)

\begin{tabular}{|c|c|c|c|c|c|c|c|}
\hline \multirow[t]{2}{*}{ Gene } & \multirow[t]{2}{*}{ Gene description } & \multirow[t]{2}{*}{ Probe set ID } & \multicolumn{2}{|c|}{ Mean \pm StDev } & \multirow{2}{*}{$\begin{array}{c}\text { Fold }^{\mathrm{b}} \\
\text { Metastatic } \\
\text { vs non- } \\
\text { metastatic }\end{array}$} & \multirow{2}{*}{$\begin{array}{c}\text { SAM Score } \\
\text { Metastatic } \\
\text { vs non- } \\
\text { metastatic }\end{array}$} & \multirow{2}{*}{$\begin{array}{c}\text { Fold }^{\mathrm{b}} \\
\text { Melanomas } \\
\text { vs nevi }\end{array}$} \\
\hline & & & $\begin{array}{c}\text { Non-metastatic } \\
\text { primary } \\
\text { melanomas }\end{array}$ & $\begin{array}{l}\text { Metastatic } \\
\text { primary } \\
\text { melanomas }\end{array}$ & & & \\
\hline TIMP1 & $\begin{array}{l}\text { TIMP } \\
\text { metallopeptidase } \\
\text { inhibitor } 1\end{array}$ & 201666_at & $1854 \pm 833$ & $\begin{array}{c}5666 \pm \\
2639\end{array}$ & 3.1 & 3.863 & 2.3 \\
\hline$V C A N$ & Versican & 204620_s_at & $1047 \pm 434$ & $2466 \pm 943$ & 2.4 & 3.788 & 2.8 \\
\hline$S P P 1$ & $\begin{array}{l}\text { Secreted } \\
\text { phosphoprotein } 1\end{array}$ & 209875_s_at & $323 \pm 218$ & $\begin{array}{c}4053 \pm \\
3159\end{array}$ & 12.6 & 3.258 & 50.2 \\
\hline CTHRC1 & $\begin{array}{l}\text { Collagen triple helix } \\
\text { repeat containing } 1\end{array}$ & 225681_at & $1307 \pm 610$ & $\begin{array}{c}3127 \pm \\
1450\end{array}$ & 2.4 & 3.240 & 4.1 \\
\hline SERPINH1 & $\begin{array}{l}\text { Serpin peptidase } \\
\text { inhibitor, clade H, } \\
\text { member } 1\end{array}$ & 207714_s_at & $536 \pm 147$ & $1114 \pm 443$ & 2.1 & 3.221 & 1.9 \\
\hline$L G A L S 1$ & $\begin{array}{l}\text { Lectin, galactoside- } \\
\text { binding, } \\
\text { soluble, } 1\end{array}$ & 201105_at & $3938 \pm 1119$ & $\begin{array}{c}8473 \pm \\
3897\end{array}$ & 2.2 & 3.144 & 1.6 \\
\hline SULF1 & Sulfatase 1 & 212354_at & $173 \pm 58$ & $483 \pm 231$ & 2.8 & 3.093 & 3.1 \\
\hline COL $4 A 1$ & $\begin{array}{l}\text { Collagen, type IV, } \\
\text { alpha } 1\end{array}$ & 211981_at & $496 \pm 222$ & $953 \pm 336$ & 1.9 & 3.011 & 3.0 \\
\hline THY1 & $\begin{array}{l}\text { Thy- } 1 \text { cell surface } \\
\text { antigen }\end{array}$ & 213869_x_at & $347 \pm 116$ & $659 \pm 242$ & 1.9 & 2.869 & 2.6 \\
\hline$M M E$ & $\begin{array}{l}\text { Membrane metallo- } \\
\text { endopeptidase }\end{array}$ & 203435_s_at & $185 \pm 50$ & $401 \pm 165$ & 2.2 & 2.825 & 2.1 \\
\hline $\begin{array}{l}L O C 541471 \\
/ N C R N- \\
A 00152\end{array}$ & $\begin{array}{l}\text { Hypothetical } \\
\text { LOC541471 / } \\
\text { non-protein coding } \\
\text { RNA } 152\end{array}$ & 225799_at & $448 \pm 237$ & $1140 \pm 623$ & 2.5 & 2.786 & 4.7 \\
\hline C13orf18 & $\begin{array}{l}\text { Chromosome } \\
13 \text { open reading } \\
\text { frame } 18\end{array}$ & 219471_at & $184 \pm 74$ & $363 \pm 124$ & 2.0 & 2.763 & 1.7 \\
\hline HEY1 & $\begin{array}{l}\text { Hairy/enhancer-of- } \\
\text { split related with } \\
\text { YRPW } \\
\text { motif } 1\end{array}$ & 44783_s_at & $564 \pm 353$ & $\begin{array}{c}1720 \pm \\
1093\end{array}$ & 3.1 & 2.762 & 2.7 \\
\hline$L O X L 2$ & Lysyl oxidase-like 2 & 202998_s_at & $211 \pm 88$ & $416 \pm 147$ & 2.0 & 2.756 & 2.0 \\
\hline$I G K C$ & $\begin{array}{l}\text { Immunoglobulin } \\
\text { kappa constant }\end{array}$ & 221651_x_at & $2934 \pm 3593$ & $\begin{array}{c}8942 \pm \\
5389\end{array}$ & 3.0 & 2.739 & 8.4 \\
\hline$A 2 M$ & $\begin{array}{l}\text { Alpha-2- } \\
\text { macroglobulin }\end{array}$ & 217757_at & $2025 \pm 800$ & $\begin{array}{c}3437 \pm \\
1277\end{array}$ & 1.7 & 2.687 & 2.8 \\
\hline$A D A M 12$ & $\begin{array}{l}\text { ADAM } \\
\text { metallopeptidase } \\
\text { domain } 12\end{array}$ & 226777_at & $63 \pm 35$ & $283 \pm 183$ & 4.5 & 2.672 & 6.1 \\
\hline
\end{tabular}




\begin{tabular}{|c|c|c|c|c|c|c|c|}
\hline \multirow[t]{2}{*}{ Gene } & \multirow[t]{2}{*}{ Gene description } & \multirow[t]{2}{*}{ Probe set ID } & \multicolumn{2}{|c|}{ Mean \pm StDev } & \multirow{2}{*}{$\begin{array}{c}\text { Fold }^{\mathrm{b}} \\
\text { Metastatic } \\
\text { vs non- } \\
\text { metastatic }\end{array}$} & \multirow{2}{*}{$\begin{array}{l}\text { SAM Score }^{\mathrm{c}} \\
\text { Metastatic } \\
\text { vs non- } \\
\text { metastatic }\end{array}$} & \multirow{2}{*}{$\begin{array}{c}\text { Fold }^{\mathrm{b}} \\
\text { Melanomas } \\
\text { vs nevi }\end{array}$} \\
\hline & & & $\begin{array}{l}\text { Non-metastatic } \\
\text { primary } \\
\text { melanomas }\end{array}$ & $\begin{array}{l}\text { Metastatic } \\
\text { primary } \\
\text { melanomas }\end{array}$ & & & \\
\hline$P A R V B$ & Parvin, beta & 37966_at & $250 \pm 78$ & $490 \pm 198$ & 2.0 & 2.660 & 1.5 \\
\hline$O L F M L 2 B$ & $\begin{array}{l}\text { Olfactomedin- } \\
\text { like 2B }\end{array}$ & 213125_at & $217 \pm 124$ & $457 \pm 190$ & 2.1 & 2.600 & 2.8 \\
\hline$S L C 2 A 3$ & $\begin{array}{l}\text { Solute carrier family } \\
2, \text { member } 3\end{array}$ & 202499_s_at & $136 \pm 69$ & $446 \pm 285$ & 3.3 & 2.594 & 3.7 \\
\hline $\begin{array}{l}I G H G 1 / \\
G 2 / M / \\
V 4-31\end{array}$ & $\begin{array}{l}\text { Immunoglobulin } \\
\text { heavy constant } \\
\text { gamma } 1 \text { / gamma } 2 \\
\text { / mu / variable } 4-31\end{array}$ & 211430_s_at & $2376 \pm 3258$ & $\begin{array}{c}8114 \pm \\
5601\end{array}$ & 3.4 & 2.585 & 21.7 \\
\hline$A R P C 1 B$ & $\begin{array}{l}\text { Actin related } \\
\text { protein } 2 / 3 \text { complex, } \\
\text { subunit } 1 \mathrm{~B}\end{array}$ & 201954_at & $1341 \pm 451$ & $\begin{array}{c}3177 \pm \\
1927\end{array}$ & 2.4 & 2.566 & 2.1 \\
\hline$D A B 2$ & $\begin{array}{l}\text { Disabled homolog } 2, \\
\text { mitogen-responsive } \\
\text { phosphoprotein }\end{array}$ & 201279_s_at & $730 \pm 401$ & $1528 \pm 764$ & 2.1 & 2.559 & 1.9 \\
\hline$N E S$ & Nestin & 218678_at & $504 \pm 251$ & $1201 \pm 691$ & 2.4 & 2.552 & 1.6 \\
\hline RNASE1 & $\begin{array}{l}\text { Ribonuclease, RNase } \\
\text { A family, } \\
1 \text { (pancreatic) }\end{array}$ & 201785_at & $1494 \pm 829$ & $\begin{array}{c}3831 \pm \\
2434\end{array}$ & 2.6 & 2.551 & 2.7 \\
\hline C20orf112 & $\begin{array}{l}\text { Chromosome } \\
20 \text { open reading } \\
\text { frame } 112\end{array}$ & 225224_at & $213 \pm 70$ & $470 \pm 233$ & 2.2 & 2.532 & 1.7 \\
\hline KDELR3 & $\begin{array}{l}\text { KDEL (Lys- } \\
\text { Asp-Glu-Leu) } \\
\text { endoplasmic } \\
\text { reticulum protein } \\
\text { retention receptor } 3\end{array}$ & 204017_at & $372 \pm 118$ & $657 \pm 256$ & 1.8 & 2.520 & 2.0 \\
\hline THBS1 & Thrombospondin 1 & 201108_s_at & $154 \pm 48$ & $274 \pm 81$ & 1.8 & 2.491 & 2.1 \\
\hline VSIG4 & $\begin{array}{l}\text { V-set and } \\
\text { immunoglobulin } \\
\text { domain containing } 4\end{array}$ & 204787_at & $187 \pm 97$ & $553 \pm 362$ & 3.0 & 2.470 & 2.1 \\
\hline SLC20A1 & $\begin{array}{l}\text { Solute carrier family } \\
20, \text { member } 1\end{array}$ & 201920_at & $499 \pm 239$ & $1208 \pm 739$ & 2.4 & 2.461 & 3.8 \\
\hline$R R M 2$ & $\begin{array}{l}\text { Ribonucleotide } \\
\text { reductase M2 }\end{array}$ & 209773_s_at & $303 \pm 140$ & $693 \pm 389$ & 2.3 & 2.434 & 3.8 \\
\hline$E G R 1$ & $\begin{array}{l}\text { Early growth } \\
\text { response } 1\end{array}$ & 227404_s_at & $2576 \pm 936$ & $\begin{array}{l}5552 \pm \\
3324\end{array}$ & 2.2 & 2.417 & 1.9 \\
\hline TMEM158 & $\begin{array}{l}\text { Transmembrane } \\
\text { protein } 158\end{array}$ & 213338_at & $175 \pm 42$ & $630 \pm 484$ & 3.6 & 2.405 & 2.7 \\
\hline FN1 & Fibronectin 1 & 210495_x_at & $3032 \pm 1186$ & $\begin{array}{l}6006 \pm \\
3292\end{array}$ & 2.0 & 2.402 & 2.2 \\
\hline CCL4 & $\begin{array}{l}\text { Chemokine } \\
\text { (C-C motif) ligand } 4\end{array}$ & 204103_at & $225 \pm 111$ & $557 \pm 338$ & 2.5 & 2.360 & $\begin{array}{c}3.9 \\
\text { (Continued) }\end{array}$ \\
\hline
\end{tabular}




\begin{tabular}{|c|c|c|c|c|c|c|c|}
\hline \multirow[t]{2}{*}{ Gene } & \multirow[t]{2}{*}{ Gene description } & \multirow[t]{2}{*}{ Probe set ID } & \multicolumn{2}{|c|}{ Mean \pm StDev } & \multirow{2}{*}{$\begin{array}{c}\text { Fold }^{\mathrm{b}} \\
\text { Metastatic } \\
\text { vs non- } \\
\text { metastatic }\end{array}$} & \multirow{2}{*}{$\begin{array}{l}\text { SAM Score }^{\mathrm{c}} \\
\text { Metastatic } \\
\text { vs non- } \\
\text { metastatic }\end{array}$} & \multirow{2}{*}{$\begin{array}{c}\text { Fold }^{\mathrm{b}} \\
\text { Melanomas } \\
\text { vs nevi }\end{array}$} \\
\hline & & & $\begin{array}{c}\text { Non-metastatic } \\
\text { primary } \\
\text { melanomas }\end{array}$ & $\begin{array}{l}\text { Metastatic } \\
\text { primary } \\
\text { melanomas }\end{array}$ & & & \\
\hline $\begin{array}{l}I G K C / \\
I G K V 1-5\end{array}$ & $\begin{array}{l}\text { Immunoglobulin } \\
\text { kappa constant / } \\
\text { variable } 1-5\end{array}$ & 214836_x_at & $600 \pm 548$ & $\begin{array}{c}1766 \pm \\
1267\end{array}$ & 2.9 & 2.360 & 4.6 \\
\hline PLAUR & $\begin{array}{l}\text { Plasminogen } \\
\text { activator, urokinase } \\
\text { receptor }\end{array}$ & 210845_s_at & $192 \pm 88$ & $499 \pm 315$ & 2.6 & 2.336 & 2.4 \\
\hline$F C G R 2 A$ & $\begin{array}{l}\text { Fc fragment of } \mathrm{IgG}, \\
\text { low affinity IIa, } \\
\text { receptor }\end{array}$ & 203561_at & $97 \pm 54$ & $490 \pm 425$ & 5.1 & 2.333 & 4.9 \\
\hline$C A L U$ & Calumenin & 200755_s_at & $702 \pm 231$ & $1251 \pm 591$ & 1.8 & 2.317 & 2.0 \\
\hline$C D K N 3$ & $\begin{array}{l}\text { Cyclin-dependent } \\
\text { kinase inhibitor } 3\end{array}$ & 209714_s_at & $157 \pm 57$ & $291 \pm 109$ & 1.9 & 2.313 & 3.0 \\
\hline $\mathrm{SH} 2 \mathrm{~B} 3$ & $\begin{array}{l}\text { SH2B adaptor } \\
\text { protein } 3\end{array}$ & 203320_at & $287 \pm 145$ & $593 \pm 307$ & 2.1 & 2.306 & 2.3 \\
\hline$R A B 20$ & $\begin{array}{l}\text { RAB20, member } \\
\text { RAS oncogene } \\
\text { family }\end{array}$ & 219622_at & $198 \pm 64$ & $562 \pm 395$ & 2.8 & 2.297 & 1.9 \\
\hline ATP6V0E2 & $\begin{array}{l}\text { ATPase, } \mathrm{H}^{+} \\
\text {transporting } \\
\text { V0 subunit } 22\end{array}$ & 213587_s_at & $340 \pm 92$ & $751 \pm 457$ & 2.2 & 2.272 & 1.8 \\
\hline $\begin{array}{l}I G L C 7 / \\
\text { IGLVI-44 }\end{array}$ & $\begin{array}{l}\text { Immunoglobulin } \\
\text { lambda constant } 7 \text { / } \\
\text { variable 1-44 }\end{array}$ & 215379_x_at & $655 \pm 752$ & $\begin{array}{c}2434 \pm \\
2071\end{array}$ & 3.7 & 2.266 & 11.6 \\
\hline PLA2G16 & $\begin{array}{l}\text { Phospholipase } \\
\text { A2, group XVI }\end{array}$ & 209581_at & $219 \pm 145$ & $408 \pm 152$ & 1.9 & 2.244 & 2.9 \\
\hline GRB10 & $\begin{array}{l}\text { Growth factor } \\
\text { receptor-bound } \\
\text { protein } 10\end{array}$ & 209409_at & $217 \pm 76$ & $463 \pm 257$ & 2.1 & 2.234 & 1.8 \\
\hline $\begin{array}{l}\text { IGLV1-44 } \\
\text { / LOC100- } \\
290481\end{array}$ & $\begin{array}{l}\text { Immunoglobulin } \\
\text { lambda variable 1-44 } \\
\text { / immunoglobulin } \\
\text { lambda light chain- } \\
\text { like }\end{array}$ & 214677_x_at & $1483 \pm 1970$ & $\begin{array}{c}5704 \pm \\
5106\end{array}$ & 3.8 & 2.196 & 19.4 \\
\hline CYR61 & $\begin{array}{l}\text { Cysteine-rich, } \\
\text { angiogenic } \\
\text { inducer, } 61\end{array}$ & 201289_at & $350 \pm 93$ & $740 \pm 451$ & 2.1 & 2.179 & 3.3 \\
\hline PCOLCE & $\begin{array}{l}\text { Procollagen } \\
\text { C-endopeptidase } \\
\text { enhancer }\end{array}$ & 202465_at & $726 \pm 289$ & $1332 \pm 712$ & 1.8 & 2.142 & 2.1 \\
\hline CHN1 & $\begin{array}{l}\text { Chimerin } \\
\text { (chimaerin) } 1\end{array}$ & 212624_s_at & $247 \pm 101$ & $457 \pm 216$ & 1.8 & 2.130 & 2.8 \\
\hline PAPSS2 & $\begin{array}{l}\text { 3'-phosphoadenosine } \\
\text { 5'-phosphosulfate } \\
\text { synthase } 2\end{array}$ & 203058_s_at & $159 \pm 74$ & $335 \pm 180$ & 2.1 & 2.113 & 2.6 \\
\hline
\end{tabular}

(Continued) 


\begin{tabular}{|c|c|c|c|c|c|c|c|}
\hline \multirow[t]{2}{*}{ Gene } & \multirow[t]{2}{*}{ Gene description } & \multirow[t]{2}{*}{ Probe set ID } & \multicolumn{2}{|c|}{ Mean \pm StDev } & \multirow{2}{*}{$\begin{array}{c}\text { Fold }^{\mathrm{b}} \\
\text { Metastatic } \\
\text { vs non- } \\
\text { metastatic }\end{array}$} & \multirow{2}{*}{$\begin{array}{l}\text { SAM Score } \\
\text { Metastatic } \\
\text { vs non- } \\
\text { metastatic }\end{array}$} & \multirow{2}{*}{$\begin{array}{c}\text { Fold }^{\mathrm{b}} \\
\text { Melanomas } \\
\text { vs nevi }\end{array}$} \\
\hline & & & $\begin{array}{c}\text { Non-metastatic } \\
\text { primary } \\
\text { melanomas }\end{array}$ & $\begin{array}{l}\text { Metastatic } \\
\text { primary } \\
\text { melanomas }\end{array}$ & & & \\
\hline$F C G R 2 C$ & $\begin{array}{l}\text { Fc fragment of } \operatorname{IgG}, \\
\text { low affinity IIc, } \\
\text { receptor }\end{array}$ & 210992_x_at & $225 \pm 90$ & $582 \pm 427$ & 2.6 & 2.095 & 2.0 \\
\hline$M C A M$ & $\begin{array}{l}\text { Melanoma cell } \\
\text { adhesion molecule }\end{array}$ & 209086_x_at & $326 \pm 62$ & $649 \pm 387$ & 2.0 & 2.079 & 1.6 \\
\hline CCL2 & $\begin{array}{l}\text { Chemokine (C-C } \\
\text { motif) ligand } 2\end{array}$ & 216598_s_at & $385 \pm 206$ & $\begin{array}{c}1346 \pm \\
1242\end{array}$ & 3.5 & 2.076 & 4.6 \\
\hline CCR1 & $\begin{array}{l}\text { Chemokine (C-C } \\
\text { motif) receptor } 1\end{array}$ & 205099_s_at & $109 \pm 74$ & $391 \pm 333$ & 3.6 & 2.064 & 4.0 \\
\hline $\begin{array}{l}S L C 2 A 14 \text { / } \\
S L C 2 A 3\end{array}$ & $\begin{array}{l}\text { Solute carrier family } \\
2, \text { member } 14 \text { / } \\
\text { solute carrier family } \\
2, \text { member } 3\end{array}$ & 216236_s_at & $272 \pm 71$ & $536 \pm 311$ & 2.0 & 2.050 & 1.8 \\
\hline$F K B P 11$ & $\begin{array}{l}\text { FK506 binding } \\
\text { protein } 11\end{array}$ & 219118_at & $269 \pm 119$ & $605 \pm 404$ & 2.2 & 2.047 & 3.0 \\
\hline$B C L 2 A 1$ & $\begin{array}{l}\text { BCL2-related } \\
\text { protein A1 }\end{array}$ & 205681_at & $292 \pm 306$ & $682 \pm 424$ & 2.3 & 2.047 & 3.6 \\
\hline$I G L L 3 P$ & $\begin{array}{l}\text { Immunoglobulin } \\
\text { lambda-like } \\
\text { polypeptide } 3 \text {, } \\
\text { pseudogene }\end{array}$ & 215946_x_at & $175 \pm 104$ & $446 \pm 317$ & 2.5 & 2.038 & 2.8 \\
\hline BST2 & $\begin{array}{l}\text { Bone marrow } \\
\text { stromal cell antigen } \\
2\end{array}$ & 201641_at & $297 \pm 145$ & $660 \pm 440$ & 2.2 & 2.037 & 2.2 \\
\hline EMILIN2 & $\begin{array}{l}\text { Elastin microfibril } \\
\text { interfacer } 2\end{array}$ & 224374_s_at & $272 \pm 136$ & $593 \pm 382$ & 2.2 & 2.034 & 1.8 \\
\hline
\end{tabular}

${ }^{a}$ Only annotated genes and the first probe set for each gene are shown. Full gene list is available by request.

${ }^{\mathrm{b}}$ Genes with $\geq 2$-fold change at least in one of the comparisons are shown.

${ }^{\mathrm{c}}$ The FDR q-value for each was $<0.001$.

(the latter two originating from the same patient) showed the highest CTHRC1 mRNA expression (Figure 1B). At the protein level, we found that WM239, MM170, and SKMEL-28 cells secreted the highest amounts of CTHRC1 (Figure 2A). Analyses of cellular CTHRC1 protein levels yielded similar results (Figure 2B).

\section{CTHRC1 is expressed coordinately with FN1, ITGB3, and NFATC2 in cells of melanocytic origin}

To reveal in which processes CTHRC1 may function, we first sought out to identify genes coordinately expressed with CTHRC1 in the microarray data from our panel of normal melanocytes, benign nevus cells, primary melanoma cells, and two melanoma cell lines (WM793 and WM239), as well as independently from a panel of 34 melanoma cell lines obtained from a data bank (E-GEOD-7152). Shared genes positively correlating with CTHRC1 expression in both sample groups comprised FN1, GPR126, NFATC2, and ITGB3 (Supplementary Table S5). Using semiquantitative RT-PCR, we then analyzed the mRNA levels of FN1 (with primers amplifying FN1 with and without the extradomains A and B: EDA+, EDA-, $\mathrm{EDB}+$, and EDB- FN1), ITGB3, and NFATC2 in WM115, WM793, WM239, MM170, SKMEL-28, SKMEL-103, SKMEL-147, and BLM melanoma cell lines. We found that these genes were expressed in a manner similar to CTHRC1 (Figure 2C). Interestingly, in cultures of primary embryonic fibroblasts, endothelial cells, melanocytes, and melanoma cells from a primary tumor, CTHRC1 and FN1 were expressed similarly at a high level in fibroblasts, 
Table 2: Gene expression in primary melanomas most significantly associated with short survival by SAM survival analysis $^{\mathrm{a}}$

\begin{tabular}{|c|c|c|c|c|}
\hline \multirow[t]{2}{*}{ Gene } & \multirow[t]{2}{*}{ Gene description } & \multirow[t]{2}{*}{ Probe set ID } & \multirow[t]{2}{*}{ SAM ${ }^{\mathrm{b}}$ Score } & \multirow{2}{*}{$\begin{array}{c}\text { Fold } \\
\text { Melanoma } \\
\text { cells vs normal } \\
\text { melanocytes }^{c}\end{array}$} \\
\hline & & & & \\
\hline PLA1A & Phospholipase A1 member A & 219584_at & 4.572 & 0.09 \\
\hline$C N P$ & $\begin{array}{l}\text { 2',3'-cyclic nucleotide } 3 \text { ' } \\
\text { phosphodiesterase }\end{array}$ & 208912_s_at & 4.369 & 0.78 \\
\hline FN1 & Fibronectin 1 & 211719_x_at & 4.265 & 4.26 \\
\hline ATP1A1 & $\begin{array}{l}\text { ATPase, } \mathrm{Na}+/ \mathrm{K}+\text { transporting, alpha } 1 \\
\text { polypeptide }\end{array}$ & 220948_s_at & 4.247 & 0.77 \\
\hline P4HA1 & Prolyl 4-hydroxylase, alpha polypeptide I & 207543_s_at & 4.147 & 4.29 \\
\hline RHOC & Ras homolog family member $\mathrm{C}$ & 200885_at & 4.131 & 2.45 \\
\hline$S C R G 1$ & Stimulator of chondrogenesis 1 & 205475_at & 3.997 & 14.61 \\
\hline$S L C 27 A 3$ & $\begin{array}{l}\text { Solute carrier family } 27 \text { (fatty acid } \\
\text { transporter), member } 3\end{array}$ & 222217_s_at & 3.891 & 0.15 \\
\hline$S 100 B$ & S100 calcium binding protein $\mathrm{B}$ & 209686_at & 3.871 & 4.62 \\
\hline SERPINA3 & $\begin{array}{l}\text { Serpin peptidase inhibitor, clade A (alpha-1 } \\
\text { antiproteinase, antitrypsin), member } 3\end{array}$ & 202376_at & 3.858 & 37.16 \\
\hline DUSP4 & Dual specificity phosphatase 4 & 226034_at & 3.745 & 1.16 \\
\hline CD63 & CD63 molecule & 200663_at & 3.738 & 0.68 \\
\hline DUSP6 & Dual specificity phosphatase 6 & 208892_s_at & 3.695 & 22.75 \\
\hline ELOVL2 & ELOVL fatty acid elongase 2 & 213712_at & 3.642 & 1.56 \\
\hline SORT1 & Sortilin 1 & 212807_s_at & 3.638 & 0.15 \\
\hline $\mathrm{SHCl}$ & $\begin{array}{l}\text { SHC (Src homology } 2 \text { domain containing) } \\
\text { transforming protein } 1\end{array}$ & 214853_s_at & 3.625 & 2.31 \\
\hline BIN3 & Bridging integrator 3 & 222199_s_at & 3.547 & 2.16 \\
\hline MFI2 & $\begin{array}{l}\text { Antigen p97 (melanoma associated) } \\
\text { identified by monoclonal antibodies } 133.2 \\
\text { and } 96.5\end{array}$ & 235911_at & 3.530 & 0.61 \\
\hline PACSIN2 & $\begin{array}{l}\text { Protein kinase } \mathrm{C} \text { and casein kinase } \\
\text { substrate in neurons } 2\end{array}$ & 201651_s_at & 3.528 & 1.18 \\
\hline$N E S$ & Nestin & 218678_at & 3.503 & 5.69 \\
\hline PSRC1 & Proline/serine-rich coiled-coil 1 & 201896_s_at & 3.497 & 2.22 \\
\hline USP54 & Ubiquitin specific peptidase 54 & 227334_at & 3.489 & 0.33 \\
\hline ETV5 & Ets variant 5 & 203349_s_at & 3.464 & 1.85 \\
\hline$C D K 2 A P 1$ & $\begin{array}{l}\text { Cyclin-dependent kinase } 2 \text { associated } \\
\text { protein } 1\end{array}$ & 201938_at & 3.462 & 1.31 \\
\hline $\begin{array}{l}\text { APOC2 / } \\
\text { APOC4 }\end{array}$ & $\begin{array}{l}\text { Apolipoprotein C-II / Apolipoprotein C-IV } \\
\text { / APOC4-APOC } 2 \text { readthrough (NMD } \\
\text { candidate) }\end{array}$ & 204561_x_at & 3.422 & 1.00 \\
\hline ARHGEF40 & $\begin{array}{l}\text { Rho guanine nucleotide exchange factor } \\
\text { (GEF) } 40\end{array}$ & 220326_s_at & 3.393 & 0.86 \\
\hline$C N N 3$ & Calponin 3 , acidic & 201445_at & 3.358 & $\begin{array}{l}2.46 \\
\text { (Continued) }\end{array}$ \\
\hline
\end{tabular}




\begin{tabular}{|c|c|c|c|c|}
\hline \multirow[t]{2}{*}{ Gene } & \multirow[t]{2}{*}{ Gene description } & \multirow[t]{2}{*}{ Probe set ID } & \multirow[t]{2}{*}{ SAM ${ }^{\mathrm{b}}$ Score } & \multirow{2}{*}{$\begin{array}{c}\text { Fold } \\
\text { Melanoma } \\
\text { cells vs normal } \\
\text { melanocytes }^{c}\end{array}$} \\
\hline & & & & \\
\hline SPRY4 & Sprouty homolog 4 (Drosophila) & 221489_s_at & 3.344 & 12.73 \\
\hline PLOD2 & $\begin{array}{l}\text { Procollagen-lysine, 2-oxoglutarate } \\
\text { 5-dioxygenase } 2\end{array}$ & 202619_s_at & 3.314 & 3.99 \\
\hline$S D C 3$ & Syndecan 3 & 202898_at & 3.295 & 4.43 \\
\hline GNG5 & $\begin{array}{l}\text { Guanine nucleotide binding protein } \\
\text { (G protein), gamma } 5\end{array}$ & 207157_s_at & 3.288 & 0.89 \\
\hline HHATL & Hedgehog acyltransferase-like & 223572_at & 3.282 & 1.06 \\
\hline $\begin{array}{l}\text { C8orf44- } \\
S G K 3 / S G K 3\end{array}$ & $\begin{array}{l}\text { C8orf44-SGK3 readthrough / Serum/ } \\
\text { glucocorticoid regulated kinase family, } \\
\text { member } 3\end{array}$ & 220038_at & 3.275 & 1.01 \\
\hline $\mathrm{CDH} 19$ & Cadherin 19 , type 2 & 206898_at & 3.269 & 1.04 \\
\hline$B I R C 7$ & Baculoviral IAP repeat containing 7 & 220451_s_at & 3.255 & 0.65 \\
\hline$V E G F A$ & Vascular endothelial growth factor A & 212171_x_at & 3.242 & 2.85 \\
\hline GAPDHP73 & $\begin{array}{l}\text { Glyceraldehyde-3-phosphate } \\
\text { dehydrogenase pseudogene } 73\end{array}$ & 234954_at & 3.231 & 4.36 \\
\hline NPTX2 & Neuronal pentraxin II & 213479_at & 3.225 & 4.97 \\
\hline$A R P C 1 B$ & $\begin{array}{l}\text { Actin related protein } 2 / 3 \text { complex, } \\
\text { subunit } 1 \mathrm{~B}, 41 \mathrm{kDa}\end{array}$ & 201954_at & 3.221 & 1.56 \\
\hline$G A N A B$ & Glucosidase, alpha; neutral AB & 211934_x_at & 3.207 & 1.82 \\
\hline SPRY2 & Sprouty homolog 2 (Drosophila) & 204011_at & 3.201 & 6.48 \\
\hline$O D C 1$ & Ornithine decarboxylase 1 & 200790_at & 3.196 & 6.31 \\
\hline $\mathrm{SH} 2 \mathrm{~B} 3$ & $\mathrm{SH} 2 \mathrm{~B}$ adaptor protein 3 & 203320_at & 3.144 & 9.22 \\
\hline$D C B L D 2$ & $\begin{array}{l}\text { Discoidin, CUB and LCCL domain } \\
\text { containing } 2\end{array}$ & 224911_s_at & 3.133 & 2.36 \\
\hline$L E F 1$ & Lymphoid enhancer-binding factor 1 & 221558_s_at & 3.131 & 2.05 \\
\hline PSMB4 & $\begin{array}{l}\text { Proteasome (prosome, macropain) } \\
\text { subunit, beta type, } 4\end{array}$ & 202243_s_at & 3.125 & 0.95 \\
\hline TIMP3 & TIMP metallopeptidase inhibitor 3 & 201147_s_at & 3.121 & 27.56 \\
\hline CSPG4 & Chondroitin sulfate proteoglycan 4 & 214297_at & 3.107 & 5.71 \\
\hline ACSL3 & $\begin{array}{l}\text { Acyl-CoA synthetase long-chain family } \\
\text { member } 3\end{array}$ & 201662_s_at & 3.104 & 4.65 \\
\hline MESDC1 & Mesoderm development candidate 1 & 223264_at & 3.102 & 0.69 \\
\hline INPP5F & Inositol polyphosphate-5-phosphatase F & 203607_at & 3.074 & 2.60 \\
\hline ST3GAL6 & $\begin{array}{l}\text { ST3 beta-galactoside alpha-2,3- } \\
\text { sialyltransferase } 6\end{array}$ & 210942_s_at & 3.065 & 0.34 \\
\hline COL9A3 & Collagen, type IX, alpha 3 & 204724_s_at & 3.059 & 10.29 \\
\hline$A P O D$ & Apolipoprotein D & 201525_at & 3.025 & 0.07 \\
\hline$T B X 2$ & T-box 2 & 40560_at & 3.003 & 1.02 \\
\hline FKBP 11 & FK506 binding protein $11,19 \mathrm{kDa}$ & 219117_s_at & 3.000 & 0.51 \\
\hline HYOU1 & Hypoxia up-regulated 1 & 200825_s_at & 2.998 & $\begin{array}{l}3.21 \\
\text { (Continued) }\end{array}$ \\
\hline
\end{tabular}




\begin{tabular}{|c|c|c|c|c|}
\hline \multirow[t]{2}{*}{ Gene } & \multirow[t]{2}{*}{ Gene description } & \multirow[t]{2}{*}{ Probe set ID } & \multirow[t]{2}{*}{ SAM $^{\mathrm{b}}$ Score } & \multirow{2}{*}{$\begin{array}{c}\text { Fold } \\
\begin{array}{c}\text { Melanoma } \\
\text { cells vs normal } \\
\text { melanocytes }\end{array}\end{array}$} \\
\hline & & & & \\
\hline SRGAPI & $\begin{array}{l}\text { SLIT-ROBO Rho GTPase activating } \\
\text { protein } 1\end{array}$ & 227484_at & 2.997 & 0.97 \\
\hline TYR & Tyrosinase & 206630_at & 2.988 & 0.02 \\
\hline $\begin{array}{l}\text { CHURC1- } \\
\text { FNTB / } \\
\text { FNTB }\end{array}$ & $\begin{array}{l}\text { CHURC1-FNTB readthrough / } \\
\text { Farnesyltransferase, CAAX box, beta }\end{array}$ & 225851_at & 2.978 & 1.49 \\
\hline PLEKHB1 & $\begin{array}{l}\text { Pleckstrin homology domain containing, } \\
\text { family B member } 1\end{array}$ & 209504_s_at & 2.976 & 0.93 \\
\hline CHST11 & $\begin{array}{l}\text { Carbohydrate (chondroitin 4) } \\
\text { sulfotransferase } 11\end{array}$ & 226372_at & 2.971 & 2.52 \\
\hline PLAT & Plasminogen activator, tissue & 201860_s_at & 2.968 & 12.24 \\
\hline$S C C P D H$ & Saccharopine dehydrogenase (putative) & 201825_s_at & 2.963 & 1.44 \\
\hline POPDC3 & Popeye domain containing 3 & 219926_at & 2.953 & 0.42 \\
\hline SOX10 & SRY (sex determining region Y)-box 10 & 209842_at & 2.948 & 0.68 \\
\hline ZMAT3 & Zinc finger, matrin-type 3 & 219628_at & 2.947 & 0.37 \\
\hline$P K M$ & Pyruvate kinase, muscle & 201251_at & 2.931 & 4.13 \\
\hline$C D K N 2 C$ & $\begin{array}{l}\text { Cyclin-dependent kinase inhibitor } 2 \mathrm{C} \\
\text { (p18, inhibits CDK4) }\end{array}$ & 204159_at & 2.928 & 1.45 \\
\hline MMP16 & $\begin{array}{l}\text { Matrix metallopeptidase } 16 \\
\text { (membrane-inserted) }\end{array}$ & 223614_at & 2.918 & 13.33 \\
\hline $\begin{array}{l}\text { MCAM / } \\
\text { MIR6756 }\end{array}$ & $\begin{array}{l}\text { Melanoma cell adhesion molecule / } \\
\text { MicroRNA } 6756\end{array}$ & 210869_s_at & 2.910 & 12.08 \\
\hline SERPINE1 & $\begin{array}{l}\text { Serpin peptidase inhibitor, clade E, } \\
\text { member } 1\end{array}$ & 202627_s_at & 2.908 & 3.15 \\
\hline PLOD3 & $\begin{array}{l}\text { Procollagen-lysine, 2-oxoglutarate } \\
\text { 5-dioxygenase } 3\end{array}$ & 202185_at & 2.905 & 1.74 \\
\hline GJB1 & Gap junction protein, beta $1,32 \mathrm{kDa}$ & 204973_at & 2.900 & 0.87 \\
\hline KCNN4 & $\begin{array}{l}\text { Potassium intermediate/small conductance } \\
\text { calcium-activated channel, subfamily } \\
\mathrm{N}, \text { member } 4\end{array}$ & 204401_at & 2.893 & 5.47 \\
\hline SHISA2 & Shisa family member 2 & 230493_at & 2.889 & 2.87 \\
\hline BACE2 & Beta-site APP-cleaving enzyme 2 & 217867_x_at & 2.875 & 0.61 \\
\hline$S 100 A 1$ & S100 calcium binding protein $\mathrm{A} 1$ & 205334_at & 2.860 & 0.68 \\
\hline$I G F B P 2$ & $\begin{array}{l}\text { Insulin-like growth factor binding protein } \\
2,36 \mathrm{kDa}\end{array}$ & 202718_at & 2.857 & 16.92 \\
\hline$U P P 1$ & Uridine phosphorylase 1 & 203234_at & 2.857 & 1.40 \\
\hline FLOT1 & Flotillin 1 & 208749_x_at & 2.847 & 0.57 \\
\hline Clorf85 & Chromosome 1 open reading frame 85 & 225401_at & 2.846 & 0.23 \\
\hline CNPY2 & Canopy FGF signaling regulator 2 & 209797_at & 2.835 & 0.83 \\
\hline
\end{tabular}

${ }^{a}$ Only annotated genes and the first probe set for each gene are shown. Full gene list is available by request.

${ }^{\mathrm{b}}$ The FDR q-value for each was $<0.001$.

'Mean expression of WM239 and WM793 melanoma cells vs that of 42V melanocytes. 

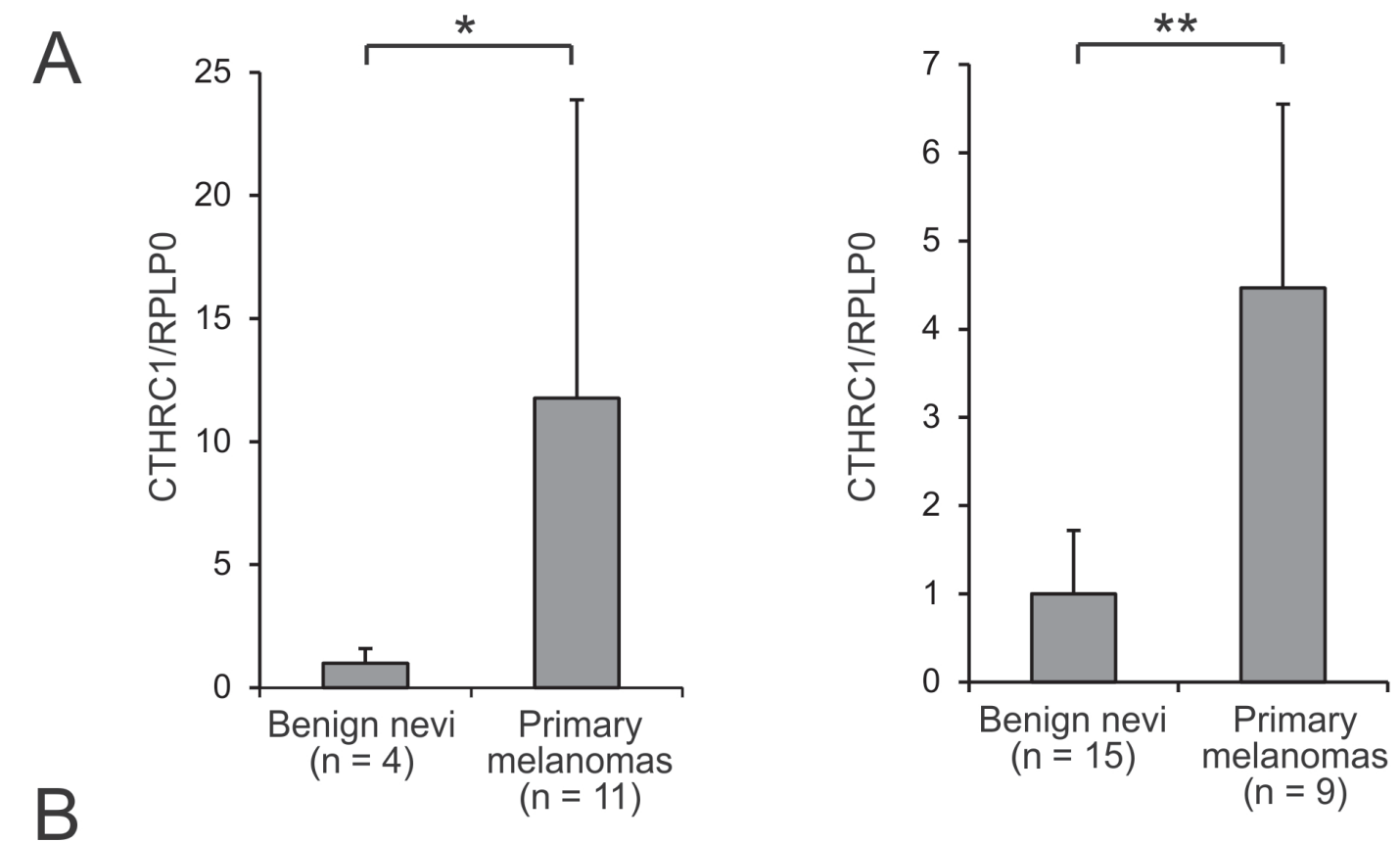

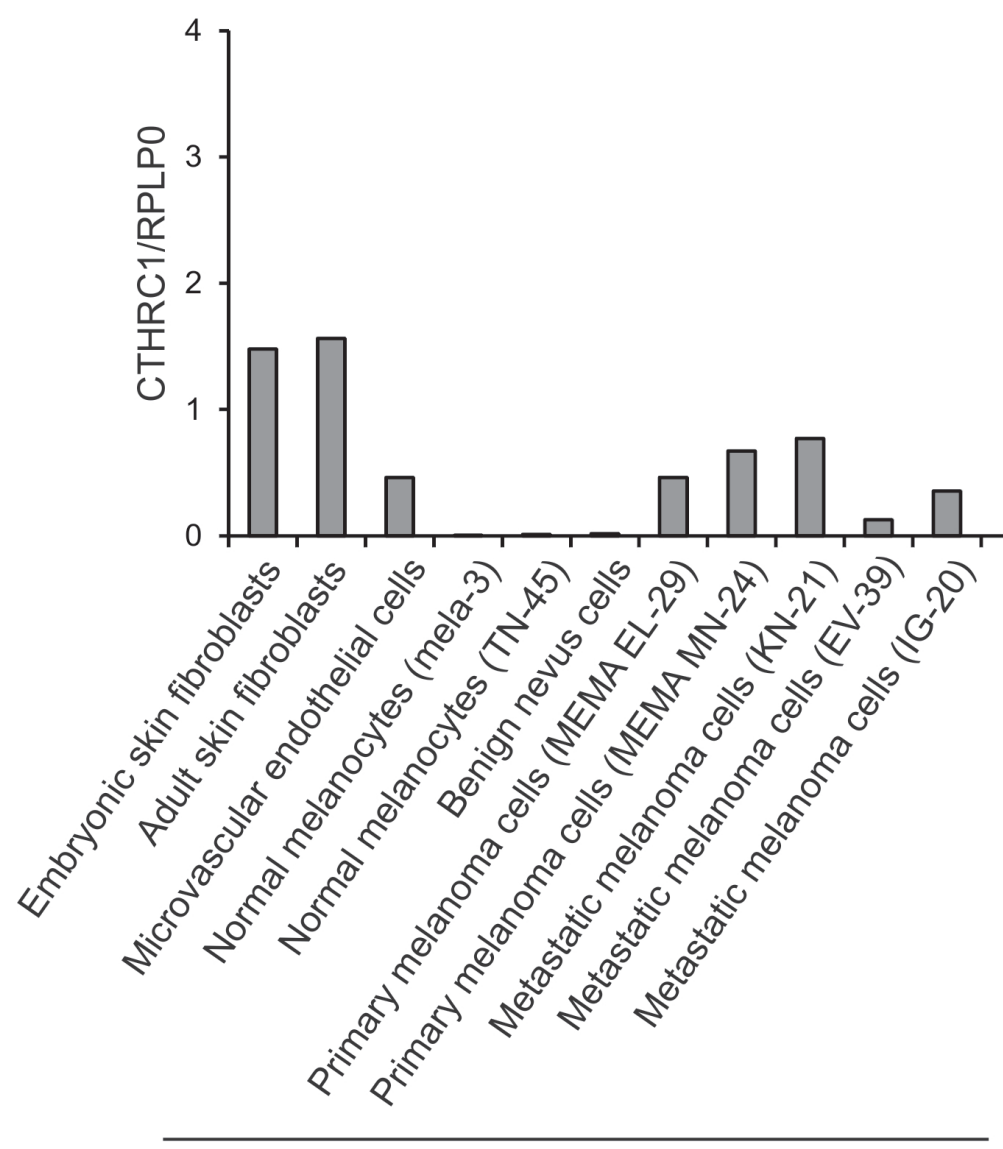

Human primary cells
Melanoma cell lines

Figure 1: CTHRC1 mRNA expression in benign and malignant melanocytic lesions and cells, and other cell types. A. Relative CTHRC1 expression levels in benign nevi and primary melanomas in two independent sample sets. CTHRC1 and RPLP0 cDNA levels were measured using qRT-PCR in triplicate for each sample. Bars represent standard deviations. ${ }^{*} P=0.0147, * * P=$ 0.000907. B. CTHRC1 expression in cultures of different primary normal and melanoma cells, and melanoma cell lines. CTHRC1 and RPLP0 cDNA levels were measured using qRT-PCR in triplicate for each sample. CTHRC1/RPLP0 levels are shown relative to that of WM239. 


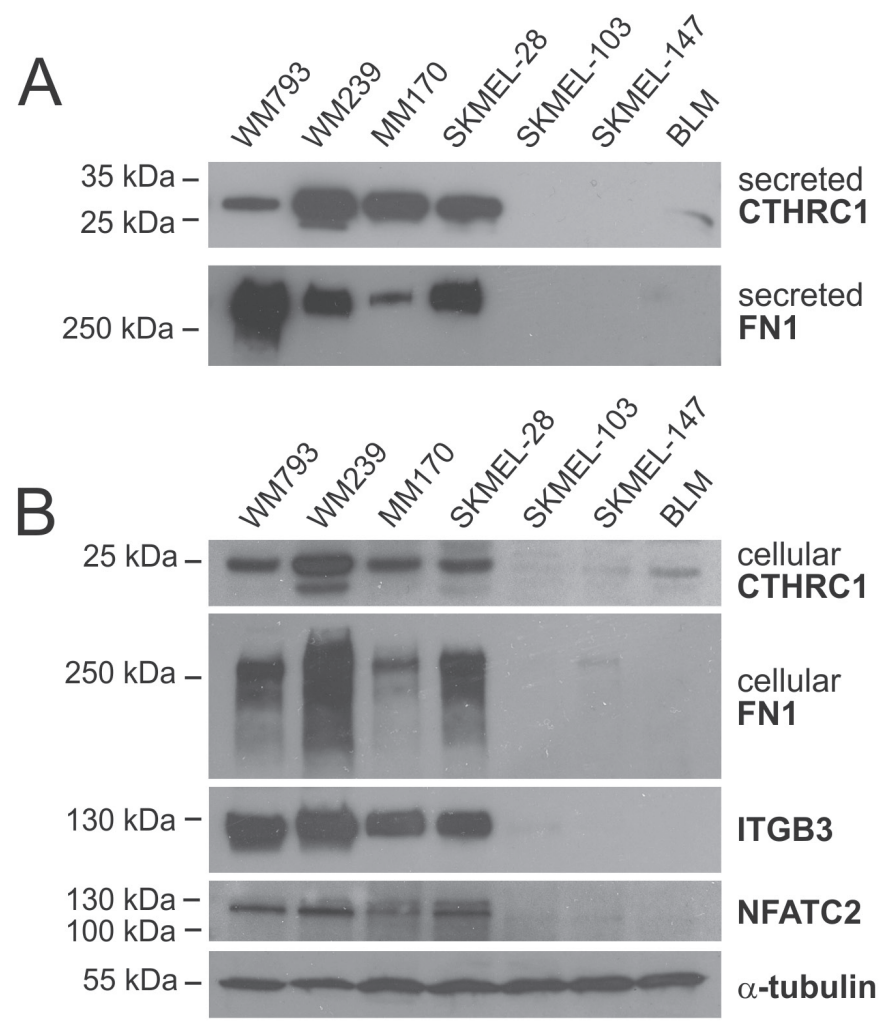

C

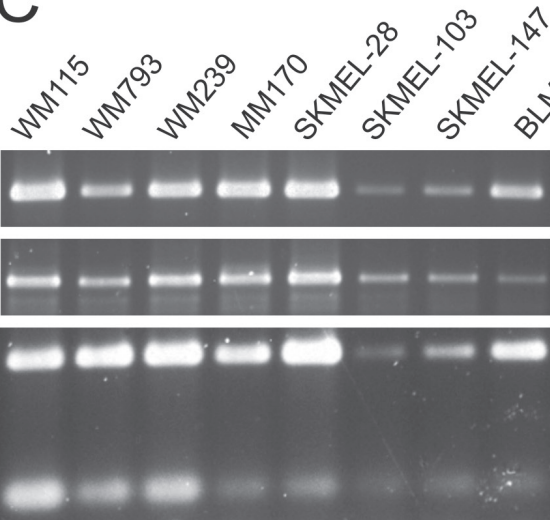

CTHRC1 full-length

CTHRC1 variant 3

FN1 EDA+

FN1 EDA-
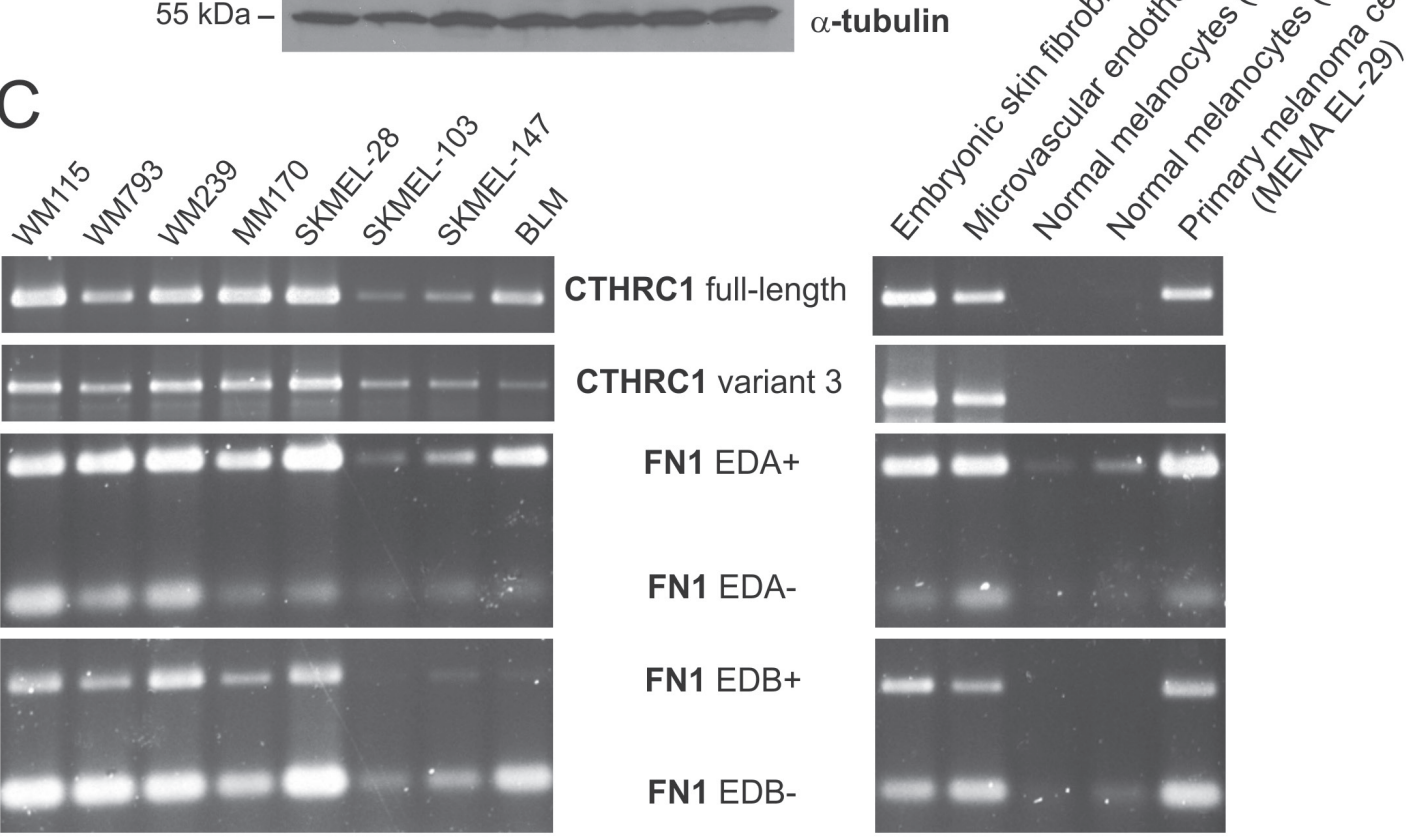

FN1 EDB+

FN1 EDB-
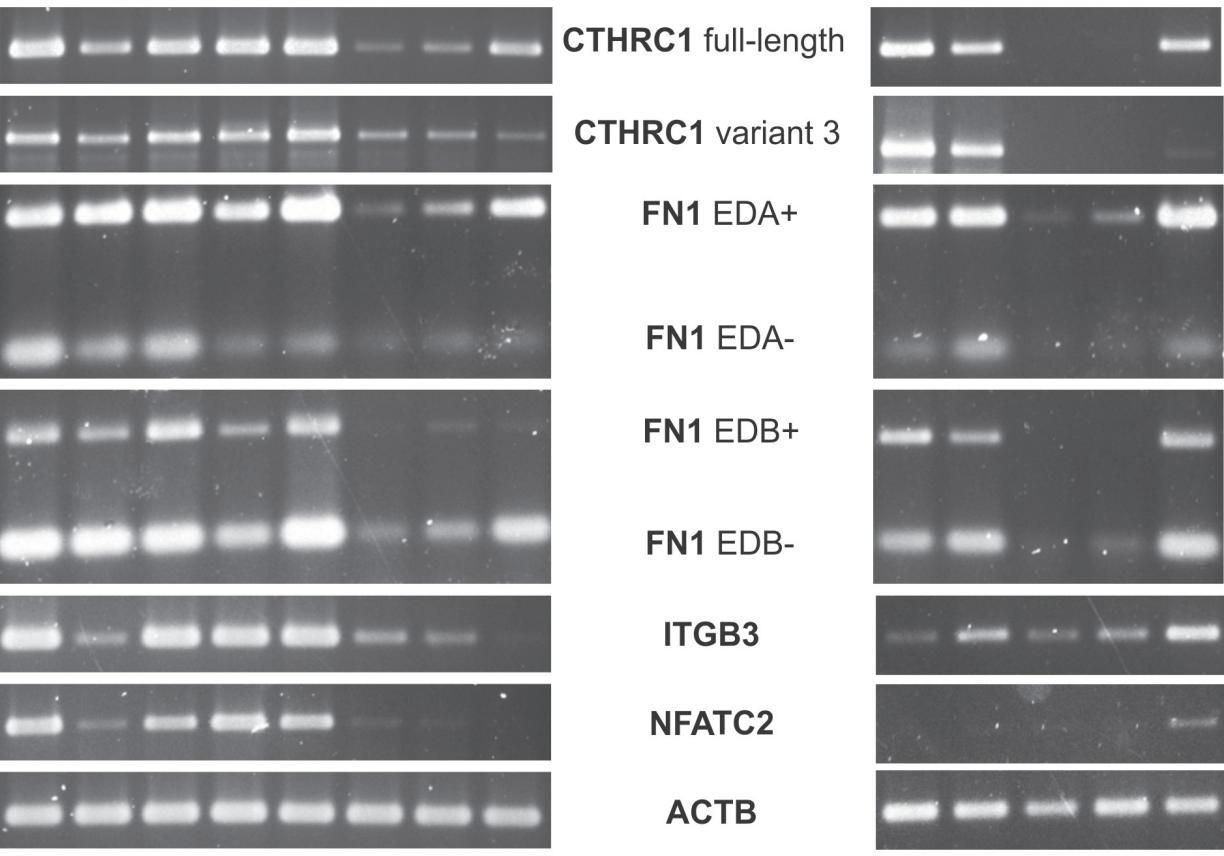

ITGB3

NFATC2
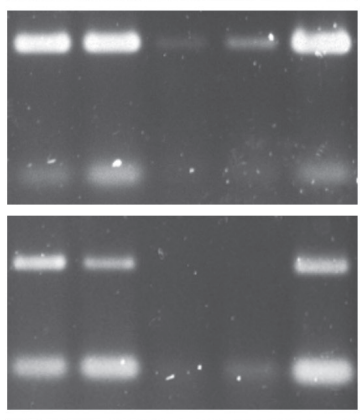

2: Expression of CTHRC1 and genes coordinately expressed with CTHRC1 in melanoma cell lines. A. Western blot analysis of CTHRC1 and FN1 protein levels in conditioned media of a panel of melanoma cell lines. B. Western blot analysis of CTHRC1, FN1, ITGB3, and NFATC2 in cellular lysates of melanoma cell lines. Alpha-tubulin was used as the loading control. C. Expression of fulllength and variant $3 \mathrm{CTHRC} 1, \mathrm{EDA}+/$ - and $\mathrm{EDB}+/$ - FN1, ITGB3, and NFATC2 in a panel of melanoma cell lines and in different primary cells analyzed using semiquantitative RT-PCR. Actin (ACTB) was used as the control. 
endothelial cells, and melanoma cells, whereas the ITGB3 expression was high in endothelial and melanoma cells but very low in fibroblasts, while NFATC2 seemed to be expressed only in the melanoma cells among the cell types tested (Figure 2C). At the protein level, FN1, ITGB3, and NFATC2 were expressed in a manner similar to CTHRC1 in our panel of melanoma cell lines (Figure 2A, 2B).

We also studied which genes are coordinately upregulated with CTHRC1 in primary melanoma tissues. Using hierarchical clustering, we found that many genes encoding ECM proteins, such as FN1, COL4A1, COL4A2, NID1, and EMILIN2, clustered with CTHRC1 (Supplementary Figure S2). Using hypergeometric testing for GO classes and KEGG pathways, we found that those genes clustering with CTHRC1 were associated with various biological processes and pathways, of which blood vessel development (GO:0001568, $P=9.1 \times 10^{-6}$ ) and locomotion (GO:0040011, $P=9.1 \times 10^{-6}$ ) proved most significant, along with ECM-receptor interaction (KEGG:04512, $P=4.0 \times 10^{-6}$ ) and focal adhesion (KEGG:04510, $P=0.00012$ ).

\section{CTHRC1 is overexpressed in melanoma tissue by both tumor and stromal cells}

Next, using immunohistochemistry we analyzed the protein expression levels and tissue distribution of CTHRC1 in benign nevi $(n=15)$, primary melanomas $(n=16)$, and melanoma lymph node metastases $(n=19)$. In benign nevi (Figure 3A), CTHRC1 showed faint to modest staining, while in primary melanomas and melanoma metastases the CTHRC1 staining varied from moderate to strong (Figure 3B, 3C). We found that the intensity of CTHRC1 staining in melanoma cells varied in individual melanoma tissue samples, with a stronger staining usually seen at the periphery of the tumor (i.e. in invasion fronts) and in areas where the melanoma cells contacted stromal cells (Figure 3D-3I). We also found strong CTHRC1 staining in fibroblasts surrounding the melanoma cell nests, and in the intimal layer of forming and newly-formed tumor blood vessels, as well as in the walls of small, normal blood vessels (Figure 3A-3I and Supplementary Figure S3), visualized using staining with the endothelial cell marker von Willebrand factor (vWF; Figure 3J, 3K). Furthermore, we also saw strong staining in the adventitia of large arteries (not shown). These data support our pathway analysis results, suggesting that CTHRC1 and genes correlating with its expression are involved in the development of blood vessels.

To confirm the CTHRC1 staining pattern, we additionally stained frozen sections from three primary melanomas with another antibody that recognized the native form of the CTHRC1 protein in Western blotting. Again, we found that CTHRC1 localized in both the melanoma cells and stromal fibroblasts (Figure 3M). In addition, CTHRC1 localized with the endothelial cell marker CD31 in blood vessels (Figure 3M, 3N). Since FN1 mRNA expression correlated with that of CTHRC1 in both melanoma cell cultures and primary melanoma tissues, we stained consecutive sections with a monoclonal antibody detecting cellular fibronectin (cFN; EDA+ FN1), finding that CTHRC1 and $\mathrm{cFN}$ co-localized in the fibroblasts or fibrillar structures surrounding melanoma cell nests and in blood vessels (Figure 3M-3O).

\section{Characterization of the CTHRC1 protein}

Since the function of CTHRC1 remains mostly unknown, we first explored the structural and molecular properties of the CTHRC1 protein. When we immunoblotted CTHRC1 under nonreducing conditions, we found that the secreted CTHRC1 existed primarily as a dimer $(\sim 56 \mathrm{kDa})$ and a trimer $(\sim 84 \mathrm{kDa})$ as well as multimers of the trimeric CTHRC1 $(\sim 168 \mathrm{kDa}$ and $\sim 252$ kDa) (Supplementary Figure S4A). The cellular CTHRC1 existed mostly as a dimer and a trimer. When we analyzed CTHRC1 under reducing conditions, the molecular weight of the secreted CTHRC1 appeared to be larger than that of the cellular CTHRC1, the weights being approximately $30 \mathrm{kDa}$ and $26 \mathrm{kDa}$, respectively (Supplementary Figure S4A). We then aimed to resolve whether the larger molecular weight is a result of some post-translational modification or whether the secreted and cellular CTHRC1 represent different isoforms. According to the Ensembl Database, four different isoforms of CTHRC1 exist, with the molecular weights of approximately 26.2 $\mathrm{kDa}$ (full-length, NP_612464.1), $12.3 \mathrm{kDa}$ (variant 2), $24.8 \mathrm{kDa}$ (variant 3, NP 001243028.1), and $16 \mathrm{kDa}$ (variant 4). Compared to the full-length protein, variant 3 contains an alternate $5^{\prime}$ exon and a translation start site, and no signal sequence for extracellular secretion. Since the qRT-PCR expression assay we used measures both the full-length and variant 3 mRNA levels, we investigated the expression of these two splice variants separately using semiquantitative RT-PCR. We found that both the full-length and variant 3 mRNAs were expressed in melanoma cell lines as well as in embryonic fibroblasts and microvascular endothelial cells (Figure 2C), although the variant 3 mRNA was expressed at a markedly lower level. We then confirmed the PCR products through sequencing. To determine if variant 3 accounts for the cellular CTHRC1 protein in melanoma cells, we knocked down the CTHRC1 expression with small interfering RNAs (siRNAs) specific to the full-length or variant 3 mRNA and with siRNAs targeting both splice variants. SiRNAs targeting the variant 3 CTHRC1 significantly reduced the variant 3 mRNA (Supplementary Figure $\mathrm{S} 4 \mathrm{~B})$, but we found no effect in the cellular protein levels of CTHRC1 (Supplementary Figure S4C). However, both the cellular and secreted CTHRC1 protein levels were reduced by siRNAs targeting the full-length CTHRC1 (Supplementary Figure S4C), suggesting that, despite the 

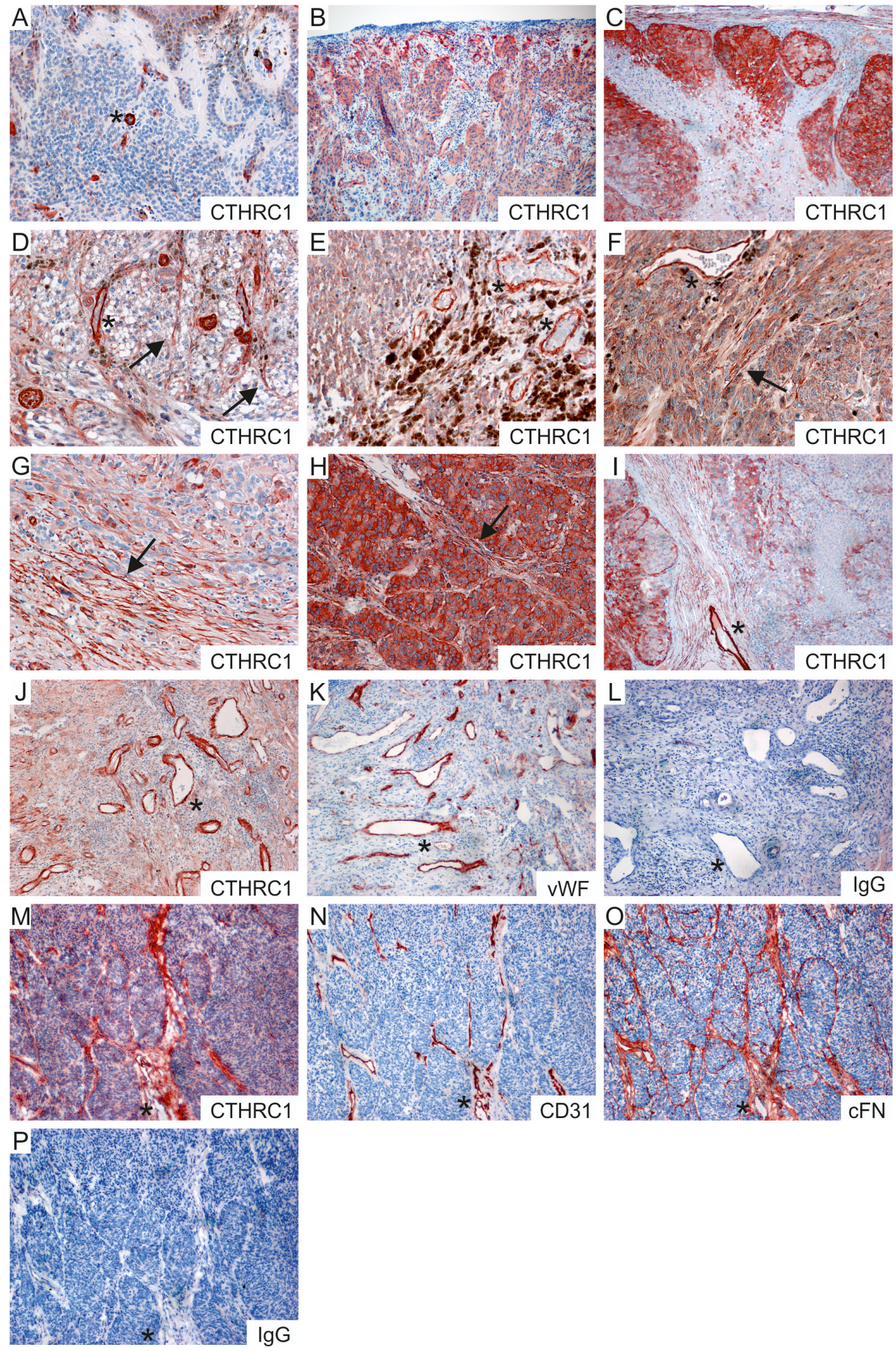

Figure 3: Immunohistochemical staining of CTHRC1, vWF, CD31, and cFN in primary melanomas and melanoma metastases. A-C. Representative stainings of CTHRC1 in a benign nevus (A), a primary melanoma (B), and a melanoma lymph node macrometastasis (C). D-I. Examples of primary melanomas (D-F) and melanoma lymph node metastases (G-I) showing different levels of CTHRC1 staining in the melanoma cells. Note that strong staining was also seen in the irregular tumor blood vessels (D, E, F, I; marked with asterisks) and in the fibroblasts (marked with arrows) surrounding the melanoma cell nests (D, F, H) and at the invasion fronts (G). J-L. Sections from a primary melanoma stained with antibodies recognizing CTHRC1 (J), vWF (K), and with a normal rabbit IgG control antibody (L). M-P. Consecutive frozen sections from a primary melanoma stained with antibodies recognizing CTHRC1 (M), CD31 $(\mathrm{N})$, and $\mathrm{cFN}(\mathrm{O})$, and with a normal rabbit $\operatorname{IgG}$ control antibody (P). (A-P) Positive immunostaining is shown in red (AEC). Original magnification 100x (B, C, I-P) and 200x (A, D-H). Examples of fibroblasts are marked with arrows, while asterisks indicate blood vessels. 
difference in molecular weight, the full-length CTHRC1 accounts for both the secreted and cellular CTHRC1, while the variant 3 protein remains relatively unexpressed.

Because the CTHRC1 protein contains a glycosylation site, we then set out to determine whether glycosylation is responsible for the different migration rates of secreted and cellular CTHRC1 in SDS-PAGE. Treating the secreted proteins and cellular lysates with $\mathrm{N}$-glycosidase $\mathrm{F}$ resulted in similar migration rates for both pools of CTHRC1 (Supplementary Figure S4D), suggesting that $\mathrm{CTHRC1}$ is further glycosylated prior to secretion.

\section{CTHRC1 is required for the migration and invasion of melanoma cells}

Since CTHRC1 overexpression has been found to enhance cell adhesion and migration [20,21], we tested the adhesion of melanoma cells (WM793, WM239, and MM170) and adult human fibroblasts on surfaces coated with the recombinant full-length CTHRC1 protein produced in human cells. Unexpectedly, we found that CTHRC1 did not support the adhesion of cells (Figure 4A). We then tested the effect of endogenous CTHRC1 on cell adhesion by knocking down CTHRC1 expression in WM239 melanoma cells by short hairpin RNAs (shRNAs) targeting all CTHRC1 variants (for the level of knockdown, see Supplementary Figure S5A-5C). We found no differences in the cell adhesion properties of the control and CTHRC1knockdown cells plated on uncoated plastic surfaces or surfaces coated with ECM proteins such as $\mathrm{cFN}$, collagen I (COL-I), and laminin (data not shown). However, when we tested the effect of endogenous CTHRC1 on cell migration through uncoated transwell inserts, the CTHRC1knockdown cells showed significantly decreased motility (4.4-fold after 22 hours; 4.3 -fold after 42 hours) compared to the control cells (Figure 4B).

To further test the effect of CTHRC1 on melanoma cell migration and invasion in a three-dimensional (3D) environment more closely mimicking the in vivo situation, we plated the cells between two layers of COL-I gel or Matrigel. In these assays, the migration and invasion capability of the WM239 CTHRC1-knockdown cells was markedly impaired compared to the wild-type or control shRNA cells (Figure 4C, 4D). It is also notable that knockdown of CTHRC1 resulted in a change in cell morphology, i.e. from the spindle shape (typical of migrating cells) of the parental cells to an epithelioid morphology (Figure 4C). It should also be noted here, that the growth rate of the WM239 CTHRC1-knockdown cells in $2 \mathrm{D}$ was not altered or was slightly increased compared to the wild-type or the control shRNA cells (data not shown). Further, knocking down CTHRC1 expression also inhibited the invasive growth of SKMEL-28 and MM170 melanoma cells embedded in thick 3D Matrigel (Figure 4E, 4F; for the levels of knockdown see Supplementary Figure S5).

\section{Regulation of CTHRC1 expression}

Since we found that CTHRC1 is coordinately expressed with the transcription factor NFATC2 in melanoma cell lines, and the NFATC2 protein has been found to be expressed by melanoma cells in vitro and in vivo [22], we studied whether NFATC2 induces the expression of CTHRC1. We first treated WM239 melanoma cells with cyclosporin A (CsA), which inhibits calcineurin that, in turn, dephosphorylates and activates NFATs. Treatment with increasing concentrations of CsA resulted in a dose-dependent reduction in the expression of the CTHRC1 protein after 24 hours (Figure 5A). In addition, the protein levels of ITGB3 (the expression of which we found to correlate with that of CTHRC1) markedly decreased after treatment with CsA for 24 hours (Figure 5A). Likewise, the protein expression levels of FN1 (which were coordinately expressed with CTHRC1) were downregulated, although only after 48 hours of incubation with CsA ( $\geq 1 \mu \mathrm{M})$ (Figure 5B), possibly due to the longer half-life of this protein. We further found that low CsA concentrations $(\leq 1 \mu \mathrm{M})$ increased the levels of phosphoErk1/2 and uncleaved caspase-3 (32-kDa zymogen) (Figure $5 \mathrm{~A}, 5 \mathrm{~B}$ ), indicating that the downregulation of CTHRC1 is not consequent to decreased cell viability. CsA treatment was also found to decrease CTHRC1 protein levels in MM170 melanoma cells (Supplementary Figure S6A). Because CsA inhibits the activity of all NFAT proteins, we additionally studied the effect of NFATC2 inhibition using specific siRNAs. The knockdown of the NFATC2 expression using these siRNAs remained incomplete, yet still resulted in a clear reduction $(50 \%)$ of CTHRC1 protein expression (Figure 5C).

Because previous studies have reported that TGF $\beta$ increases CTHRC1 expression and that CTHRC1, in turn, inhibits TGF $\beta$ signaling in different cell types $[20,23]$, we examined the role of TGF $\beta$ in the regulation of CTHRC1 in melanoma cells by inhibiting TGF $\beta$ signaling with increasing concentrations of a specific TGFß-receptor I/ALK-5 inhibitor SB505124. We found a dose-dependent reduction of the CTHRC1 protein levels in both WM239 and MM170 cells after 24 and 48 hours of inhibition (Figure 5D, Supplementary Figure S6B, and data not shown).

In addition, since we found that the expression of ITGB3 correlated with that of CTHRC1 in melanoma cells (Supplementary Table S5) and primary melanoma tissues (data not shown) (and we found no changes in the ITGB3 expression levels in CTHRC1-knockdown cells, data not shown), we examined whether CTHRC1 could be a downstream target of ITGB3 signaling. Indeed, incubating WM239 cells with neutralizing antibodies to $\alpha_{v} \beta_{3}$ integrin for 48 hours resulted in a reduction in the CTHRC1 protein levels (Figure 5E).

Furthermore, since oncogenic BRAF has been found to activate NFAT signaling in melanoma [24], 


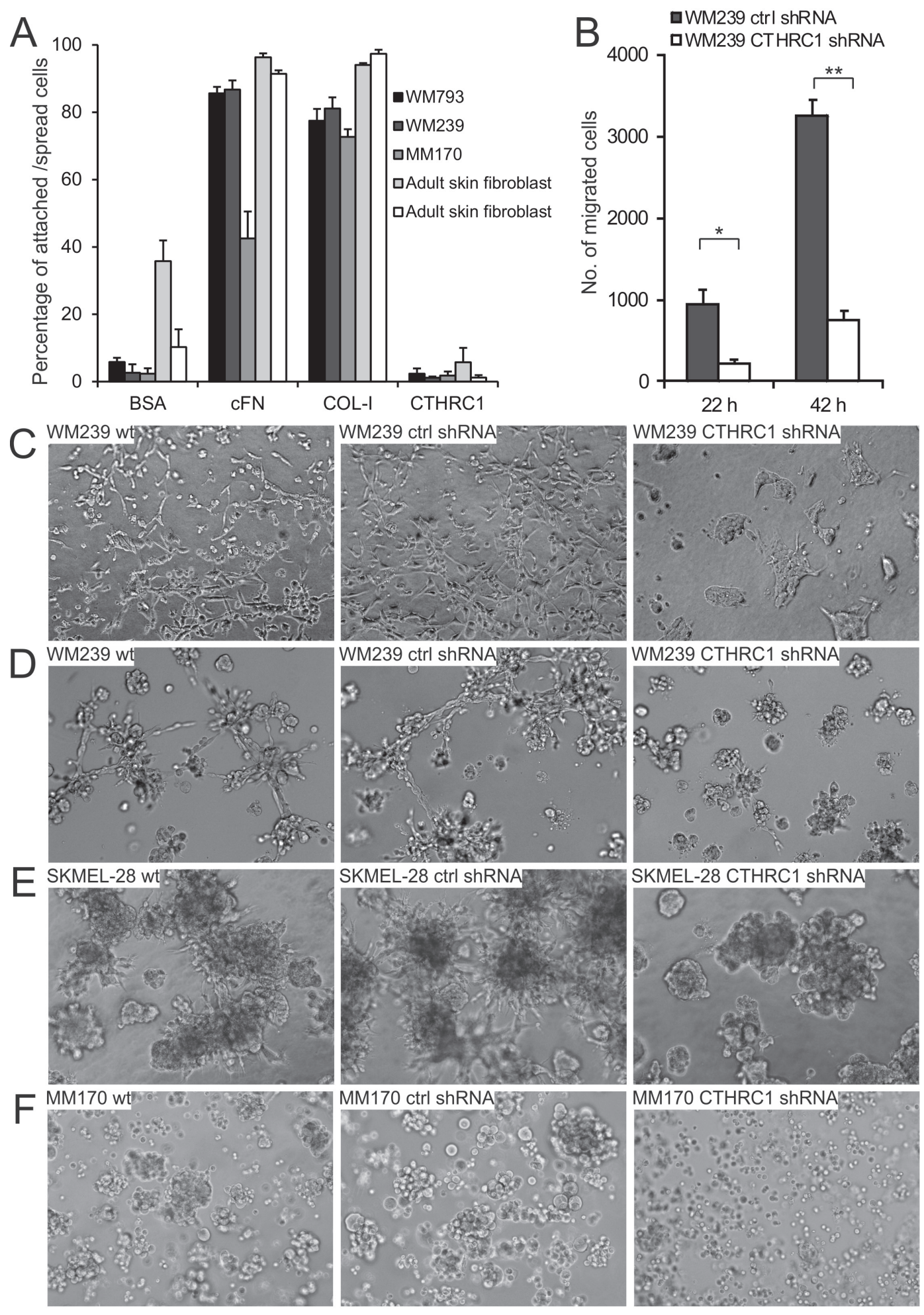

Figure 4: Effect of CTHRC1 on cell adhesion, migration, and invasion. A. Adhesion of WM793, WM239, and MM170 melanoma cell lines and primary human fibroblasts on surfaces coated with cFN, COL-I, and CTHRC1. BSA was used as the control. Values consists of means \pm standard deviations of three replicates. B. The effect of CTHRC1 on cell migration. The number of WM239 control (ctrl) and CTHRC1-knockdown cells migrated through transwell inserts after incubation for 22 and 42 hours. Values consist of means \pm standard deviations of three replicates. ${ }^{*} P=0.002,{ }^{*} P<0.0001$. C-F. The effect of CTHRC1 on the invasive growth of melanoma cells in 3D gels. Culture of WM239 wild-type (wt), control, and CTHRC1-knockdown cells embedded between two layers of 3D collagen-I gel for four days (C) and between two layers of Matrigel for five days (D). Culture of SKMEL-28 (E) and MM170 (F) wt, control, and CTHRC1-knockdown cells embedded between two layers of Matrigel for eight days. 
and we found that CTHRC1 is expressed at high levels mainly in BRAF mutant melanoma cell lines, we examined the effect of BRAF inhibition on CTHRC1 expression. Treating the WM239 cells (BRAF V600D mutant) with increasing concentrations of the BRAF inhibitor Dabrafenib for 48 hours resulted in a dose- dependent reduction of BRAF activity (measured by the reduced phospho-Erk1/2 levels) and the expression of the CTHRC1 protein (Figure 5F). Similarly, CTHRC1 protein levels were also decreased in MM170 cells (BRAF V600E mutant) after treatment with Dabrafenib for 24 hours (Supplementary Figure S6C).

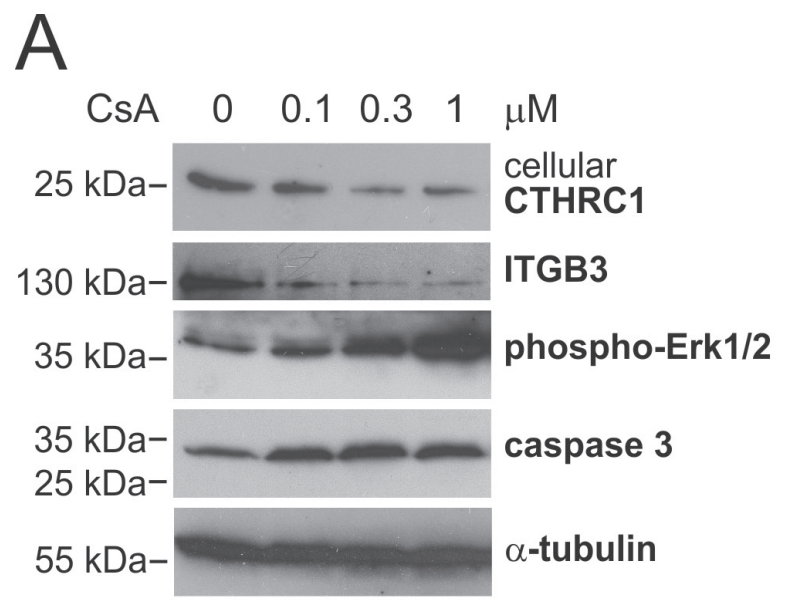

B
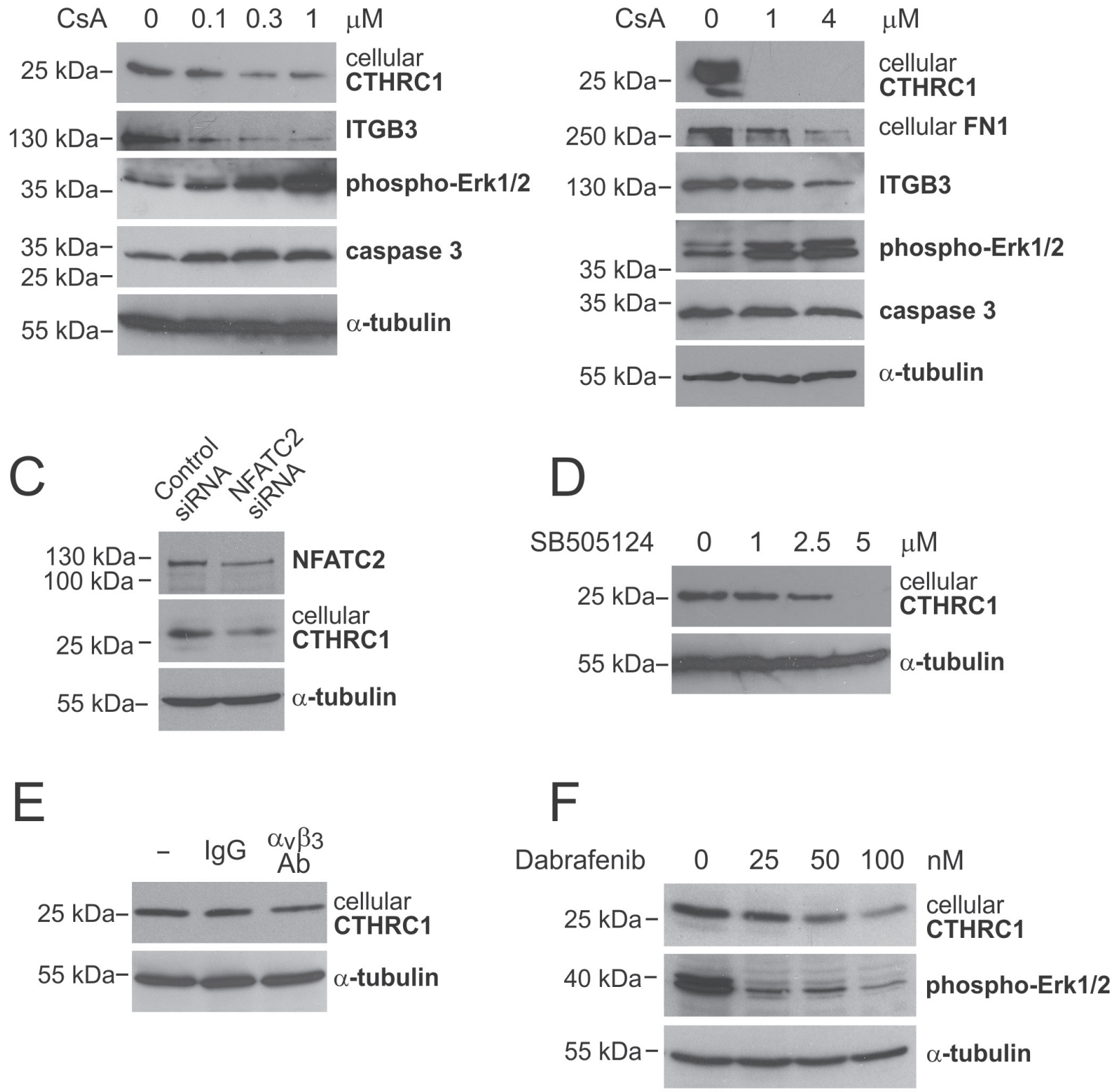

Figure 5: Regulation of CTHRC1 expression. A and B. Western blot analysis of CTHRC1 and other proteins of interest in WM239 cells treated without or with increasing concentrations of cyclosporin A (CsA) for 24 hours (A) and 48 hours (B). C. Western blot analysis of NFATC2 and CTHRC1 in WM239 control and NFATC2-knockdown cells 72 hours after siRNA transfection. D. Western blot analysis of CTHRC1 in WM239 cells treated without or with increasing concentrations of TGF $\beta$-receptor I/ALK-5 inhibitor SB505124 for 48 hours. E. Western blot analysis of CTHRC1 in WM239 cells treated without or with $10 \mu \mathrm{g} / \mathrm{ml}$ control antibodies (IgG) and neutralizing antibodies to integrin $\alpha_{v} \beta_{3}$ for 48 hours. F. Western blot analysis of CTHRC1 and phospho-Erk1/2 in WM239 cells treated without or with increasing concentrations of BRAF inhibitor Dabrafenib for 48 hours. Alpha-tubulin was used as the loading control. 


\section{Gene expression changes in CTHRC1- knockdown cells}

To unravel the molecular mechanisms of the CTHRC1 action, we analyzed the gene expression profiles of the WM239 control shRNA and CTHRC1-knockdown cells using microarray analyses. We found 41 probe sets representing 36 annotated genes downregulated (with $\geq 1.5$-fold change and $\geq 100$ difference in the expression values) in the CTHRC1-knockdown cells compared to the control shRNA cells (Supplementary Table S6). The most downregulated gene in the knockdown cells was CTHRCl itself with a 2.8-fold reduction in expression. The second most downregulated gene was aldo-keto reductase family 1, member $\mathrm{C} 3$ ( $A K R 1 C 3$ ), which has been reported to be overexpressed in several cancers [25-27], and to increase the migration and invasion of cervical cancer cells and to change the organization of their cytoskeleton [28]. Other downregulated genes included fatty acid binding protein 7 (FABP7), previously linked to the proliferation, migration, and invasion of tumor cells [29, 30], and cofilin 1 (CFL1), a central regulator protein of actin dynamics in migrating cells (reviewed in [31]). Furthermore, WNT5A, an activator of the non-canonical Wnt signaling pathway, also emerged among the downregulated genes.

We further confirmed the downregulation of CTHRC1, AKR1C3, WNT5A, and FABP7 mRNA expression levels in the CTHRC1-knockdown cells by qRT-PCR (Supplementary Table S7). To confirm the reproducibility of these results, we studied the expression levels of these genes in a separate knockdown experiment in
WM239 cells. These CTHRC1-knockdown cells showed an even larger decrease in the mRNA levels of CTHRC1 and the other downregulated genes compared to those of the control shRNA cells (Supplementary Table S7) To further evaluate the generality of these findings, we analyzed the expression levels of these potential downstream targets of CTHRC1 in another melanoma cell line, MM170, with similar results (Supplementary Table S7). In particular, AKR1C3 was highly downregulated in the CTHRC1knockdown cells.

\section{Effect of CTHRC1 knockdown on tumorigenesis of WM239 melanoma cells in nude mice}

To study the effect of CTHRC1 on tumorigenesis in nude mice, we injected WM239 CTHRC1-knockdown and control shRNA-expressing cells $\left(6 \times 10^{6}\right)$ with or without Matrigel subcutaneously into the lower flanks of the mice. As CTHRC1 expression was clearly associated with tumor progression in clinical human melanomas, we unexpectedly found that the growth rate of CTHRC1-knockdown cells was increased compared to the control shRNA cells in two repeated experiments (Figure 6 and Supplementary Figure S7). When excised, the knockdown tumors were found to be markedly softer than the control tumors. First, we confirmed the knockdown of CTHRC1 mRNA expression levels by qRT-PCR analyses, which revealed about 10 -fold decrease in expression (data not shown). Histologically, the tumors in both groups were heterogeneous (Supplementary Figure S8), similar to the parental WM239 cell line. The knockdown tumors showed consistently more necrotic areas,

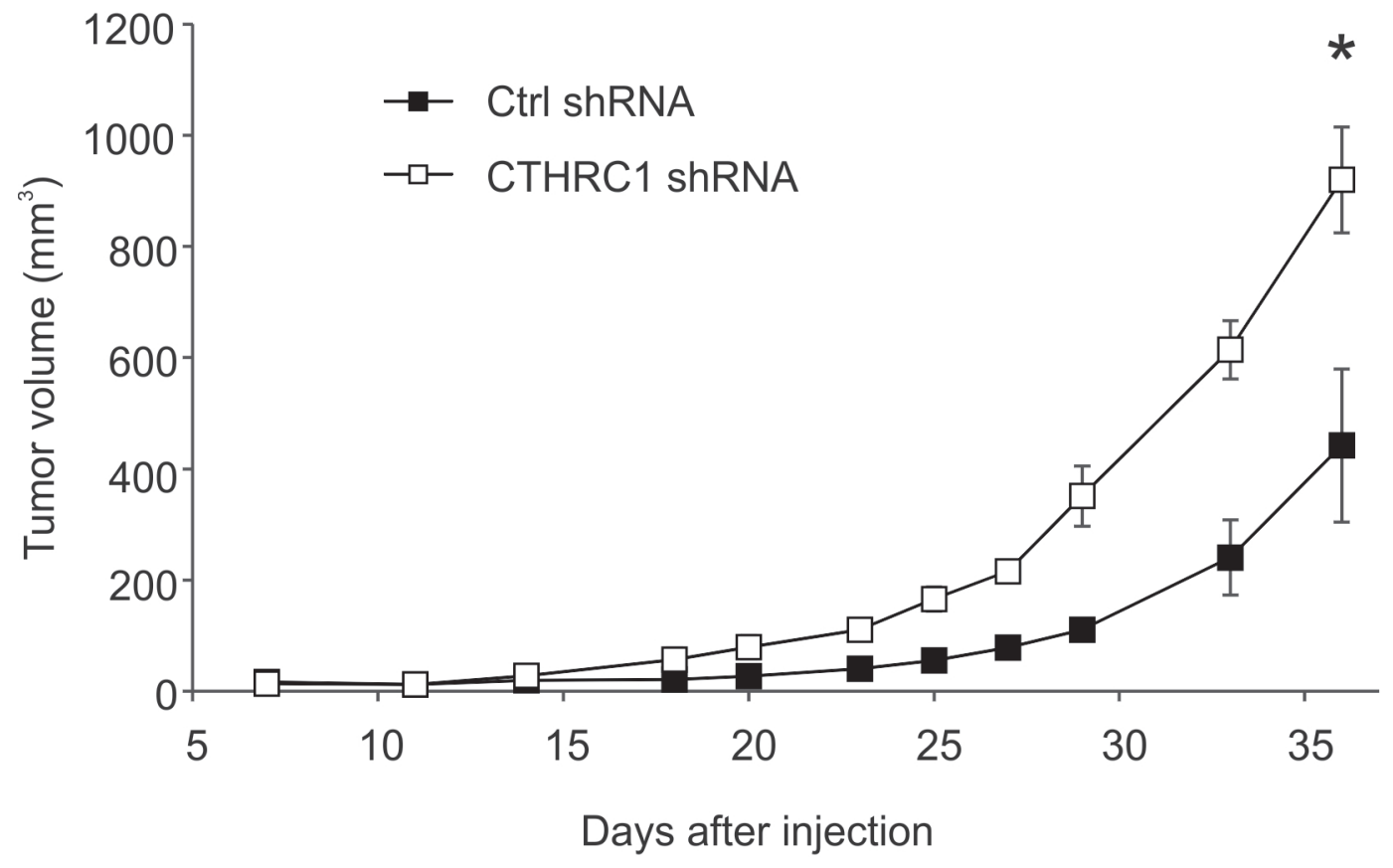

Figure 6: Growth curves of tumors induced by control (ctrl) shRNA-expressing and CTHRC1-knockdown WM239 cells in nude mice. Cells $\left(6 \times 10^{6}\right)$ were injected subcutaneously into the lower flank of the individual mice (six mice per group). Tumor volume was measured with a caliper two to three times per week. Bars represent standard deviations. ${ }^{*} P<0.00001$. 
which, as a result of fluid accumulation, may contribute to the looser structure of the tissue and larger size of the tumors. We then studied other possible mechanisms for the increased size of the knockdown tumors by analyzing the proliferation and survival statuses of the cells. Immunostaining of the DNA synthesis marker, minichromosome maintenance complex component 7 (MCM7), appeared to show increased intensity in the CTHRC1-knockdown tumors as compared to the control tumors (Supplementary Figure S8E-S8H), regardless of the tumor size. Staining of the apoptosis marker, cleaved/active caspase 3, counterintuitively suggested also increased apoptosis in the CTHRC1-knockdown tumors but only locally beside the necrotic areas (Supplementary Figure S8I-8L). Whether this is due to reduced angiogenesis or other factors in the CTHRC1-knockdown cells remains to be seen.

We then stained the tumors for the melanoma marker S100, the expression/secretion levels of which are known to be associated with metastasis and poor patient prognosis $[32,33]$. Interestingly, the CTHRC1knockdown tumors showed a markedly decreased staining of S100 (Supplementary Figure S8M-S8P). Of additional interest, the smallest control tumor with a high CTHRC1 expression showed high invasive capability (muscle invasion) and formed a rapidly growing secondary tumor (data not shown).

\section{DISCUSSION}

Melanoma, a highly aggressive and heterogeneous disease, continues to present a significant therapeutic challenge. In our research, we aimed to identify genes commonly associated with the development and progression of primary melanomas by screening the gene expression profiles of fresh/frozen benign nevi and non-metastatic and metastatic primary melanomas (difficult to obtain without interfering with diagnostics). The tissue samples also contained the associated stromal compartment, allowing us to identify changes occurring in the tumor microenvironment as well. Interestingly, we found several genes involved in the ECM modification, such as FN1 and P4HA1, which may be expressed by both melanoma and stromal cells, to be associated with metastasis and patient prognosis. Determining if these changes are associated with the formation of tubular FN1-, COL-I-, and tenascin C-containing fibrillar structures, which we have previously suggested to be invasion channels for melanoma cells $[34,35]$, remains of interest. In support of this idea, collagen prolyl hydroxylases have been found to promote the invasion and metastasis of breast cancer cells through collagen deposition [36]. Another important tumor-promoting process in the microenvironment is inflammation. Consistent with this, we found that the pro-inflammatory cytokines S100A8 and S100A9 (reviewed in [37]), as well as the chemokine receptor CXCR4, were highly and significantly upregulated in primary melanomas compared to benign nevi. The importance of S100A proteins in melanoma development has been less studied, but the expression of CXCR4 has been reported to predict poor prognosis in melanoma [38]. In addition to tumor cells, CXCR4 is expressed by several other cell types, including macrophages and endothelial cells, and the CXCL12CXCR4 pathway is associated with tumor progression, metastasis, and angiogenesis (reviewed in [39]), also providing an attractive target for melanoma therapy. Another potential therapy target is MIR21, which we found to be highly upregulated in primary melanomas (significant upregulation validated using qRT-PCR, data not shown). The expression of MIR21 has further been shown to increase during melanoma progression and to predict poor survival [40]. Consistent with this, we found that both CXCR4 and MIR21 were upregulated in metastatic compared to non-metastatic primary melanomas. Interestingly, several protease inhibitors, such as TIMP1, TIMP3, and SERPINE2, were also upregulated in metastatic primary melanomas. Although protease inhibitors have been expected to display antitumorigenic properties, they have also been shown to play pro-tumorigenic roles and to be associated with poor prognosis in various cancers [41-45], warranting more detailed studies of their functions in melanoma as well.

Most interestingly, we found that many of the genes we have previously identified as upregulated in melanoma lymph node metastases $[35,46]$ were already upregulated in metastatic primary tumors, including SPP1 and CTHRC1 as well as the ECM protein-encoding genes VCAN, LGALS1, and FN1. Among these, we further found that SPP1, CTHRC1, LGALS1, and, most significantly, FN1 mRNA correlated with a poor survival (Table 2, Supplementary Figure S1, and data not shown), although these results must be validated in a larger data set. Interestingly, we found that CTHRC1 and FN1 mRNA expression correlated in primary melanocytes, nevus cells, and melanoma cells, as well as in melanoma cell lines and primary melanoma tissues. Other genes correlating with CTHRC1 expression in melanoma cell lines included the transcription factor NFATC2 and ITGB3. The coordinate expression of these genes may at least partly result from regulation by TGF $\beta$, since all of them have been suggested to be TGF $\beta$ target genes [20,47-49]. We have also found that TGF $\beta$ signaling is activated during the progression of melanomas [35]. It appears that NFATC2 may further increase the expression of CTHRC1, FN1, and ITGB3, given that we found their protein levels to decrease after treatment with CsA or specific NFATC2 siRNAs. Indeed, ITGB3 expression has recently been suggested to be increased by the calcineurin-NFAT signaling [50]. Furthermore, we found that the inhibition of $\alpha v \beta 3$ integrin activity using neutralizing antibodies reduced CTHRC1 expression, suggesting a regulatory role for ITGB3 in CTHRC1 expression. ITGB3 has been suggested to 
play an important role in melanoma progression since it is overexpressed in VGP primary melanomas and in melanoma metastases [51], and its overexpression induces the conversion of melanoma cells from the radial to vertical growth phase [52]. Integrin $\alpha v \beta 3$ functions as a receptor for many ECM proteins containing the classical integrin-recognition RGD motif, including vitronectin, FN1, fibrinogen, vWF, thrombospondin, and SPP1 [53-55]. Thus, elevated levels of FN1 may induce the coordinate expression of CTHRC1 in melanoma cells by activating the $\alpha v \beta 3$ integrin receptor. The $\alpha v \beta 3$ integrin receptor may also be activated by other ligands expressed by melanoma cells, such as SPP1, as we recently reported [56]. Interestingly, SPP1, one of the most highly upregulated genes in melanoma progression, has also been shown to promote osteoclast survival by activating calcineurin-NFAT signaling through integrin binding via its RGD motif [57].

CTHRC1 is overexpressed in many cancers, including gastric [58], pancreatic [21], hepatocellular [59], breast [60], and non-small cell lung cancer [61], as well as in melanoma [62]. In melanoma, CTHRC1 has previously been reported to be expressed by melanoma cells. However, we found that CTHRC1 is expressed in in vitro cultured cells and in human melanoma tissue samples by both melanoma and stromal cells. The stromal expression of CTHRC1 has also been noted in breast cancer, where CTHRC1 is expressed in breast cancer cells $[60,63]$ as well as in the stromal myoepithelial cells and myofibroblasts [64]. Originally, CTHRC1 was identified as a protein transiently expressed in injured arteries by fibroblasts of the remodeling adventitia and by smooth muscle cells of the neointima, and it was found to promote the migration of these cells in vitro [20]. Consistent with this, we found that the genes correlating with CTHRC1 expression in primary melanoma tissues were most significantly associated with blood vessel development and locomotion. We detected a high CTHRC1 expression in the tumor-associated fibroblasts/activated fibroblasts and in the intimal layer of aberrantly shaped immature tumor blood vessels. We also found staining in the walls and adventitia of normal blood vessels. Importantly, no obvious fibroblastic staining was found in the benign nevi, consistent with an earlier study reporting that fibroblastlike cells in normal tissues do not express CTHRC1 [65]. It thus appears that the upregulation of CTHRC1 mRNA in the primary melanomas compared to benign nevi primarily results from an increase in blood vessel formation and from the recruitment and activation of stromal fibroblasts. We should also note that the activation of fibroblasts is likely independent of the mutational status of melanomas cells [66]. As a result of this and the increased angiogenesis, CTHRC1 is likely to be universally increased in melanomas. In melanoma cells, the most intensive CTHRC1 staining was found in areas contacting stromal cells, suggesting that the interplay between melanoma cells and fibroblasts is important in inducing CTHRC1 expression. Furthermore, because CTHRC1 is a secreted protein, it may function as a paracrine factor in the tumor microenvironment, promoting the migration and invasion of many cell types regardless of the cell-type that has produced it.

Interestingly, the genes coordinately expressed with $C T H R C 1$, i.e. ITGB3, NFAT, and FN1, have all been implicated in angiogenesis, suggesting that these molecules may be associated with the increased angiogenesis and blood vessel density detected in melanomas. In support of this idea, integrin $\alpha v \beta 3$ has long been recognized as an important receptor in endothelial cells. ITGB3 forms a complex with VEGFR2 in a VEGF-dependent manner, leading to the phosphorylation of both receptors and the promotion of the adhesion, spreading, and migration of endothelial cells $[67,68]$. VEGF has also been found to activate NFAT signaling in endothelial cells, and to promote endothelial cell migration and angiogenesis through NFAT signaling [69]. FN1, in turn, is essential in vascular morphogenesis [70], and both the EDA- and EDB-containing FN1 isoforms have been proposed as vascular markers in tumors $[71,72]$. Furthermore, we have previously demonstrated that the EDA-containing FN1 (cFN) is upregulated in forming or newly formed blood vessels in melanoma lymph node metastases [35]. Here, we found that cFN co-localized with CTHRC1 in the blood vessels of primary melanoma tumors. It may also be noteworthy that we found neuropilin 2 (NRP2), a cell surface receptor for VEGF (reviewed in [73]) and TGF $\beta$ [74], to be coordinately expressed with CTHRC1 in melanoma cell lines (data not shown). This pro-angiogenic factor is expressed by tumor cells as well as vascular and lymphatic endothelial cells, and functions as an important mediator of melanoma and endothelial cell communication [75].

The function of CTHRC1 in melanoma remains largely unknown. The knockdown of CTHRC1 expression in melanoma cells has been found to decrease melanoma cell migration in vitro [62], a finding consistent with our results. Importantly, we further found that the knockdown of CTHRC1 inhibited the invasive growth of melanoma cells in 3D Matrigel and COL-I gels. How then does CTHRC1 exert its effect on cell migration and invasion? One of the genes that we found to be downregulated in the CTHRC1-knockdown cells was WNT5A. CTHRC1 has been suggested to bind WNT5A and stabilize the binding of Wnt to its receptor, thus activating Wnt signaling [76]. Consequently, the activation of Wnt signaling may create a positive feedback loop, where the expression of both WNT5A and CTHRC1 is maintained through increased signaling of the downstream protein kinase $\mathrm{C}$ [77] and calcineurin-NFAT pathways [78, 79], respectively. In addition, the CFL1 gene downregulated in the CTHRC1knockdown cells may be activated by a calcineurindependent mechanism [80]. Both genes are thus potential effectors of CTHRC1-induced cell migration and invasion, and their importance and functions in these processes remain interesting subjects for future research. 
In our in vivo xenograft experiments in nude mice, we found that knockdown of CTHRC1 in WM239 melanoma cells increased tumor growth. It is recently recognized that cancer cells cannot proliferate and invade at the same time $[81,82]$. Thus, one explanation to our rather unexpected result in nude mice may be that CTHRC1 may regulate the switch from proliferation to invasion, as we found CTHRC1 to promote invasion but not proliferation in vitro. Notably, CTHRC1 has recently been reported to promote invasion and metastasis of ovarian carcinoma cells in xenograft assays [83]. These experimental settings are, however, complicated by the fact that CTHRC1 is also expressed by stromal cells and thus for reliable results the experiments should be performed in CTHRC1-knockout animals. Further, the subcutaneous xenograft transplantation model does not recapitulate human melanomas, as it does not provide the proper microenvironment for the co-evolution of tumor and stromal cells taking place in actual human tumors. In any case, our studies on clinical human melanomas show that CTHRC1 expression in primary melanomas correlates with lymph node metastasis and poor patient prognosis. Further, we have found CTHRC1 to be expressed in lymph node macrometastases at a similar high level to that in primary melanomas ([35] and data not shown).

In conclusion, we found that several genes associated with inflammation, angiogenesis, and ECM modification were commonly upregulated during the development, progression, and metastasis of primary melanomas. Our results indicate that changes in the stromal gene expression and the tumor microenvironment promote tumor progression and metastasis, providing many new potential targets for therapy and markers to predict disease outcomes. These findings are consistent with recent studies on colorectal cancer [84] and other cancers (reviewed in $[19,85]$ ). Here, we found that one such potential target gene, CTHRC1, was overexpressed by both melanoma cells and the surrounding activated fibroblasts, and showed high expression in tumor blood vessels as well. Interestingly, in melanoma cells, we found that CTHRC1 was coordinately expressed with the invasion- and angiogenesis-promoting genes FN1, ITGB3, and NFATC2. In functional analyses, we found that CTHRC1 was required for cell migration/invasion and may regulate the switch between the proliferative and invasive phenotypes. The expression of CTHRC1 was found to be induced by NFATC2, which has been implicated in the pathogenesis of many solid tumors, including pancreatic, lung, and breast cancers [86, 87]. NFATs may function as integrators of various oncogenic signaling pathways, including MAPK, Wnt, and Notch [88] and, thus, represent promising targets for cancer therapy. Targeting NFAT signaling specifically in the tumor cells and in the tumor endothelium may most effectively inhibit NFAT-promoted tumor progression [87]. It is notable that CTHRC1 and many of the genes that we found to be associated with CTHRC1 overexpression during melanoma progression are also induced by TGF $\beta$. Of further interest, the switch of the tumor-suppressive function of TGF $\beta$ towards tumor progression [89] has recently been reported to be driven by the activation of NFATs [90], and NFAT has been found to cooperate with TGF $\beta$ in inducing the epithelial-mesenchymal transition in breast cancer cells [91]. Thus, combined inhibition of both NFAT and TGF $\beta$ signaling pathways in melanomas represents an interesting possibility, since it may interfere with both tumor cell invasion and angiogenesis.

\section{MATERIALS AND METHODS}

\section{Patient samples}

We obtained fresh primary cutaneous melanomas $(n=36)$, melanoma lymph node metastases $(n=19)$, and benign nevi $(n=31)$ from healthy volunteers by surgical excision at Helsinki University Central Hospital using protocols approved by the Ethics Committee of Helsinki University Central Hospital. All patients provided informed consent. Half of each tissue specimen was fixed in formalin for histopathological and immunohistochemical analyses, and the other half was immediately frozen in liquid nitrogen or immersed in RNAlater RNA stabilization solution (Life Technologies, Carlsbad, CA, USA) for gene expression analyses using DNA microarrays and RT-PCR.

\section{RNA isolation and purification}

RNA was extracted from cells and tissues using the RNeasy kit (>200 nt RNA, Qiagen, Hilden, Germany) or the mirVana miRNA isolation kit (total-RNA, Life Technologies). Frozen tissue specimens were ground in liquid nitrogen and homogenized in lysis buffer with a 21-gauge needle. Tissues immersed in RNAlater were homogenized in lysis buffer with Lysing matrix D and the FastPrep FP120 Cell Disrupter (Qbiogene/ MP Biomedicals, Santa Ana, CA, USA) according to the manufacturer's instructions. Pigment removal was performed by adsorption to Bio-Gel P-60 as described elsewhere [46]. The quality of the purified RNA was assessed by agarose gel electrophoresis or by Bioanalyzer 2100 (Agilent Technologies, Santa Clara, CA, USA).

\section{Microarray analysis}

Normal nevi $(n=11)$ and primary melanomas $(n=21)$, as well as RNA from normal melanocytes, nevus cells, primary melanoma cells, and melanoma cell lines, were analyzed using the Human Genome U133 Plus 2.0 array (Affymetrix, Santa Clara, CA, USA) as previously described [46]. The microarray data is deposited in the ArrayExpress database (https://www.ebi.ac.uk/arrayexpress/), accession no. E-MTAB-1862. 


\section{Statistical analysis of microarray data}

The microarray probe signals were preprocessed using the RMA algorithm (RMAExpress 1.1.0, http:// rmaexpress.bmbolstad.com/). Gene probe sets with a mean difference $<100$ and a change of $<1.5$-fold between different sample groups were filtered off before rank ordering using SAM [92] (http://www-stat.stanford. edu/ tibs/SAM/). SAM was performed using the samr package in $\mathrm{R}$ (version 3.1.2) (http://www.r-project.org/) using 4000 random permutations. Delta was chosen so that the false discovery rate (FDR) was $<1 \%$.

Gene lists were subjected to hypergeometric testing for GO classes and KEGG pathways using the Chipster v3.4.1 software (http://chipster.csc.fi/). We considered GO classes and pathways with $P$-values $<0.05$ and at least two observed genes as significantly overrepresented. Hierarchical clustering of genes was performed with the Chipster software using Pearson's correlation as the distance metric and average linkage as the clustering method. Gene lists were also subjected to gene enrichment analysis using the Molecular Signature Database (MSigDB, v5.0, Broad institute, MA, USA, http://www.broadinstitute. org/gsea/msigdb/index.jsp), Hallmark gene set collection.

\section{RT-PCR analyses and DNA sequencing}

One $\mu \mathrm{g}$ of RNA was reverse-transcribed into cDNA as previously described [46] and used for the analysis of mRNA expression levels using semiquantitative and quantitative PCR. Semiquantitative RT-PCR analyses were performed as previously described [46], with the primers and PCR variables listed in Supplementary Table S8. The sequencing of PCR fragments is described elsewhere [35].

Real-time qRT-PCR analyses were performed using the ABI PRISM 7700 Sequence Detection System instrument and software (Life Technologies). Relative mRNA expression levels of CTHRC1 were measured using TaqMan assay Hs00298917_m1, that of AKR1C3 using Hs00366267_m1, WNT5A using Hs00998537_m1, and FABP7 using Hs00361426_m1. Expression levels of all genes were normalized with the pre-developed TaqMan assay for ribosomal protein, large, P0 (RPLP0) (Life Technologies).

\section{Immunohistochemistry}

Formalin-fixed paraffin-embedded sections $(5 \mu \mathrm{m})$ were deparaffinized, rehydrated in a graded ethanol series, and treated with trypsin $(0.1 \%$ in $\mathrm{PBS})$ at $37^{\circ} \mathrm{C}$ for 20 minutes (CTHRC1 and $\mathrm{vWF}$ ) or subjected to heat-induced epitope retrieval in citrate buffer (0.01M, pH 6.0) (MCM7 and cleaved caspase 3$)$ or in Tris-EDTA buffer $(\mathrm{pH} 8.0)$ (S100). The endogenous peroxidase activity was blocked with $0.3 \% \mathrm{H}_{2} \mathrm{O}_{2}$ in methanol for 30 minutes. Sections were blocked with CAS-block reagent (Zymed Laboratories/ Life Technologies) and/or $1.5 \%$ to $10 \%$ normal goat serum (Vector Laboratories, Burlingame, CA, USA) in PBS for 1 hour. A panel of CTHRC1 antibodies (N2C3 from Genetex, Irvine, CA, USA; 11647-RP02 from Sino Biological Inc., Beijing, China; ab85739 and ab54181 from Abcam, Cambridge, UK; clone 1G12 from Abnova, Taipei, Taiwan; clone Vli55 from Maine Medical Center Research Institute, Scarborough, ME, USA; H-213 from Santa Cruz Biotechnology, Dallas, TX, USA) were tested for their performance in immunohistochemistry, selecting the best for further analyses (Figures 3J, 3L, 3M, 3P and Supplementary Figure S9A). Specimens were then stained with the rabbit polyclonal antibodies (pAb) to CTHRC1 (N2C3, GeneTex; 1:200) and to vWF (A0082, DAKO/ Agilent Technologies; 1:1000; for the visualization of blood vessels), or rabbit monoclonal antibodies to MCM7 (clone EP1974Y, Epitomics/Abcam; 1:100) or to cleaved caspase 3 (clone 5A1E, Cell Signaling Technology, Danvers, MA, USA; 1:200) in PBS containing 0.1\% normal goat serum at $4^{\circ} \mathrm{C}$ overnight. For S100 staining, specimens were incubated with a rabbit pAb to $\mathrm{S} 100$ (Z-0311, Dako/Agilent Technologies; 1:100) for 30 minutes and detected using the ultraView Universal DAB Detection kit (Ventana/Roche) according to standard protocol.

Cryosections $(5 \mu \mathrm{m})$ for CTHRC1 staining were fixed with $4 \%$ paraformaldehyde for 25 minutes and permeabilized in $0.1 \%$ Triton X-100 in PBS for 10 minutes. The endogenous peroxidase activity was blocked with $0.3 \% \mathrm{H}_{2} \mathrm{O}_{2}$ in PBS for 10 minutes. Sections were blocked in $5 \%$ bovine serum albumin (BSA) and $10 \%$ normal goat serum in PBS for 1 hour, and incubated with rabbit pAb to CTHRC1 (11647-RP02, Sino Biological Inc.; 1:780) in PBS containing 5\% normal goat serum at $4^{\circ} \mathrm{C}$ overnight. In CD31 and cFN staining, endogenous peroxidases were inactivated by $0.3 \% \mathrm{H}_{2} \mathrm{O}_{2}$ in methanol for 30 minutes. Sections were blocked in $1 \%$ BSA and in CAS-block for 30 minutes (for CD31) or in 1\% normal goat serum in PBS for 1 hour (for $\mathrm{cFN}$ ), and incubated with the mouse monoclonal antibody $(\mathrm{mAb})$ to $\mathrm{CD} 31$ (clone JC70A, DAKO/Agilent Technologies; 1:200) in CAS-block or cFN (clone FN-3E2, Sigma-Aldrich, St. Louis, MO, USA; 1:400) in PBS containing 1\% normal goat serum at $4^{\circ} \mathrm{C}$ overnight. In all stainings, normal mouse or rabbit IgG (of the same isotype when applicable) served as the negative control (shown for CTHRC1 in Figure 3M, 3P, and in Supplementary Figure S9A). Immunodetection for both the paraffin-embedded and cryosections was performed using the Vectastain $\mathrm{ABC}$ kit (Vector Laboratories) according to the manufacturer's protocol using 3-amino-9-ethylcarbatzole (AEC) or 3, 3 - diaminobenzidine (DAB) as the chromogen. Sections were counterstained with Mayer's hematoxylin and mounted with Aquamount. Images were taken using a Nikon Eclipse 80i microscope, a Digital Sight DS-5M camera, and the NIS-Elements F 2.20 software (Nikon, Tokyo, Japan). 


\section{Western blotting}

We performed the analysis of proteins from wholecell lysates [93] and conditioned media [94, 95] as previously described. A panel of CTHRC1 antibodies (N2C3 from Genetex; 11647-RP02 from Sino Biological Inc.; ab85739, ab54181, ab135716, and clone 16D04 from Abcam; clone 1G12 from Abnova; H-213 from Santa Cruz Biotechnology) were tested for their performance in Western blotting, and the rabbit pAbs ab85739 and 11647RP02 (for immunoblotting under nonreducing conditions) were selected for the study. The specificity of the antibodies was tested by analyzing the CTHRC 1 protein in the control and CTHRC1-knockdown cells using Western blotting and immunocytochemistry (Supplementary Figure S5B, 5C, 5E, 5G, and Supplementary Figure S9B9D). In addition, rabbit pAb to ITGB3 (H-96, Santa Cruz Biotechnology), rabbit mAb to phospho-Erk1/2 (20G11, Cell Signaling Technology), rabbit antiserum to cleaved caspase 3 (anti-hCCP32-p17, Merck Frosst, Quebec, Canada), and mouse mAbs to FN1 (NCL-FIB, Novocastra/ Leica Biosystems, Wetzlar, Germany) and NFATC2 (BD Biosciences, Franklin Lakes, NJ, USA or 4G6-G5, Santa Cruz Biotechnology) were used to detect the respective proteins. Mouse mAbs to alpha-tubulin (DM1A, Abcam) and actin (JLA20, Merck Millipore, Billerica, MA, USA) were used as the loading controls. The densities of the protein bands were quantified using Image Studio Lite (LI-COR Biotechnology, Lincoln, NE, USA).

\section{$\mathrm{N}$-glycosidase F-treatment}

Proteins from cell lysates $(50 \mu \mathrm{g})$ and conditioned medium $(30 \mu \mathrm{g})$ were treated (after reduction and denaturation) with or without recombinant $N$-glycosidase F (Roche, Mannheim, Germany) ( 0.6 units/ $\mu$ g of protein) in sodium phosphate buffer (100 mmol/L, $\mathrm{pH} 7.2)$ supplemented with $1 \%$ NP-40 and 1 X Complete protease inhibitor (Roche) at $37^{\circ} \mathrm{C}$ overnight.

\section{Cell culture}

We isolated and cultured primary human melanocytes and melanoma cells as described elsewhere [96]. The human VGP melanoma cell lines WM115 (BRAF V600D mutation; from ATCC-LGC Standards, Borås, Sweden) and WM793 (BRAF V600E; provided by Dr. Meenhard Herlyn, Wistar Institute, Philadelphia, PA, USA), the metastatic melanoma cell lines MM170 (BRAF V600E; from CellBank Australia, Westmead, Australia), SKMEL-28 (BRAF V600E; from ATCC-LCG), and WM239 (BRAF V600D; from Dr. M. Herlyn), as well as the primary human adult and embryonic skin fibroblasts (provided by Drs. A.-M. Ranki and A. Vaheri, University of Helsinki, Finland, respectively) were cultured in RPMI 1640 medium (Sigma-Aldrich) supplemented with 10\% FBS (Gibco/ Life Technologies) and antibiotics. Metastatic melanoma cell lines SKMEL-103 (NRAS Q61R) and SKMEL-147 (NRAS Q61R) (both originating from Dr. Alan Houghton, Memorial Sloan-Kettering Cancer Center, New York, NY, USA; provided by Dr. Maria Soengas, Spanish National Cancer Research Center, Madrid, Spain) as well as the BLM cell line (NRAS Q61R; from Dr. van Muijen, Radboud University, Nijmegen Medical Centre, Nijmegen, Netherlands) were cultured in Dulbecco's Modified Eagle Medium (Gibco/Life Technologies) supplemented with $10 \%$ FBS and antibiotics. Primary human microvascular endothelial cells (Life Technologies) were cultured in growth factor - supplemented Medium 131 (Gibco/Life Technologies).

\section{Inhibitors and blocking antibodies of signaling pathways}

CsA was purchased from Santa Cruz Biotechnology, the TGF $\beta$ receptor I (ALK5) inhibitor SB505124 from Sigma-Aldrich, and the BRAF inhibitor Dabrafenib (GSK2118436A) from Selleckchem (Houston, TX, USA). The function-blocking antibody to integrin $\alpha v \beta 3$ (LM609) was acquired from Merck Millipore.

\section{Short hairpin RNA lentiviral particle transduction}

WM239, SKMEL-28, and MM170 were transduced with shRNA lentiviral particles (Santa Cruz Biotechnology) targeting CTHRC1 (sc-77043-V) or with scrambled control shRNA particles (sc-108080) in duplicate in two separate experiments according to the manufacturer's instructions. Pools of puromycin-resistant cells were used in the assays.

\section{Transfection of small interfering RNA}

WM239 cells were transfected with siRNA duplexes targeting the full-length CTHRC1 (sense strand: 5'-GCCA GACGCUGACCACGUUCCUCdTdC-3'; antisense strand: 5'-GAGAGGAACGUGGUCAGCGUCUGGCUC-3';), the variant 3 CTHRC1 (sense strand: 5'-CAGGUAGGAGCAU CACAGUCAAGdCdT-3'; antisense strand: 5'-AGCUUGA CUGUGAUGCUCCUACCUGGC-3'; both designed using the Integrated DNA Technologies RNAi Design Tool and manufactured by Integrated DNA Technologies, Coralville, IA, USA), or with duplexes targeting all CTHRC1 variants (sc-77043) or with scrambled control siRNA duplexes (sc37007, both from Santa Cruz Biotechnology) according to Santa Cruz Biotechnology's instructions. The cells were used in assays 48 hours after transfection. In addition, WM239 cells were transfected with duplexes targeting NFATC2 (sc-36055, Santa Cruz Biotechnology).

\section{Immunofluorescence staining}

Cells were grown on glass coverslips for two to three days and fixed with $4 \%$ paraformaldehyde for 30 
min. After permeabilization with $0.1 \%$ Triton X-100 in PBS for 10 min and blocking with 1\% BSA (Invitrogen/ Life Technologies) and 10\% normal goat serum in PBS for 1 hour, the cells were incubated with $5 \mu \mathrm{g} / \mathrm{ml}$ of rabbit pAb to CTHRC1 (11647-RP02, Sino Biological Inc.) diluted in PBS containing 5\% normal goat serum for 2 hours. Then, cells were washed three times with PBS and incubated with Alexa Fluor 488-conjugated goat antirabbit secondary antibodies (Invitrogen/Life Technologies) in PBS containing $1 \%$ normal goat serum. F-actin was immunostained with Alexa Fluor 594-conjugated phalloidin (Molecular Probes/Life Technologies). Finally, the cells were mounted with the Vectashield H-1200 mounting media containing DAPI (Vector Laboratories), and images were obtained using a Zeiss Axiophot2 epifluorescence microscope (Carl Zeiss, Oberkochen, Germany), QImaging Retiga 4000R digital camera, and QCapture Pro 6-software (QImaging, Surrey, Canada).

\section{Cell adhesion assay}

Flat-bottomed 96-well plates were coated with $100 \mu \mathrm{l}$ of $10 \mu \mathrm{g} / \mathrm{ml}$ BSA (fatty acid-free, SigmaAldrich), cFN (USBiologicals, Salem, MA), COL-I (BD Biosciences), and recombinant human CTHRC1 (Sino Biological Inc.) for 2 hours at $37^{\circ} \mathrm{C}$, and washed three times with PBS. Cells $\left(2 \times 10^{4}\right)$ were added to the wells in serum-free medium, and attached and spread cells were photographed and counted after incubation for 1 hour at $37^{\circ} \mathrm{C}$.

\section{Cell migration assay}

Cells $\left(3 \times 10^{4}\right)$ were added to a Falcon cell culture insert ( $8 \mu \mathrm{m}, \mathrm{BD}$ Biosciences) in serum-free medium $(200 \mu \mathrm{l})$, and the lower chamber was filled with $800 \mu \mathrm{l}$ of growth medium. After incubation for 22 or 42 hours, the cells were fixed in $3.5 \%$ paraformaldehyde and stained with $0.5 \%$ crystal violet (in $20 \%$ methanol). Nonmigrated cells on the upper surface were scraped off, and migrated cells on the lower surface were photographed and counted. Experiments were repeated three times, and the results were analyzed using a two-tailed $t$-test.

\section{Three-dimensional collagen I gel and matrigel invasion assays}

Melanoma cell invasion was assayed in a 3D collagen I gel (COL-I, high concentration, rat tail) and growth factor-reduced Matrigel (both from BD Biosciences) as described previously [34, 94]. Briefly, 30,000 WM239, SKMEL-28, or MM170 cells were cast between two gel layers, and medium supplemented with $10 \%$ serum was added on top of the gels (replenished every third day). The invasion patterns of the cells were analyzed daily using microscopy and photography.

\section{Xenograft nude mice assays}

Animal studies were carried out according to the Animal Experiment Board in Finland (ELLA) for the care and use of animals under the licenses ESAVI-6285-04.10.07-20151. CTHRC1 shRNA- and control shRNA-expressing WM239 cells were injected $(6 \mathrm{x}$ $10^{6}$ cells in $75 \mu \mathrm{l}$ of Opti-MEM I [Gibco/Life Technologies] with $75 \mu \mathrm{l}$ of growth factor-reduced Matrigel or in 100 $\mu$ of Opti-MEM I) subcutaneously into the lower flank of 5 and 7-week-old female BALB/c nu mice in the two experiments, six animals per group (one inoculation per animal). Tumor growth was followed two to three times per week using a caliper (measuring in three dimensions), and the mice were euthanized at day 36 when the largest tumors reached the ethical limits. The tumors were removed, cut in half, and one half was fixed in formalin and embedded in paraffin and the other half was frozen in isopentane. For histological and immunohistochemical analyses, 5- $\mu \mathrm{m}$ sections were cut from paraffin blocks and stained with H\&E and with antibodies against MCM7, active caspase 3 , and S100, as described in the Immunohistochemistry section above. Part of the frozen tissue was subjected to RNA extraction and qRT-PCR for CTHRC1 expression analysis, as described in the RT-PCR analyses section.

\section{Statistical analysis}

Statistical analyses were performed using a twotailed Welch's $t$-test, where we considered $P<0.05$ significant. Survival curves were plotted according to the Kaplan-Meier method and compared using the logrank test in the SPSS 21.0 software program (SPSS, Chicago, USA).

\section{ACKNOWLEDGMENTS}

We thank Leena Saikko, Eija Heiliö, and Ulla Kiiski for technical assistance.

\section{FUNDING}

This work was supported by the Academy of Finland, the Cancer Foundation/Cancer Society of Finland, Helsinki University Central Hospital Research Funds, and the Instrumentarium Science Foundation.

\section{CONFLICTS OF INTERESTS}

The authors declare that they have no conflicts of interests.

\section{Abbreviations}

BSA, bovine serum albumin; cFN, cellular fibronectin; COL-I, collagen I; CsA, cyclosporine A; 
ECM, extracellular matrix; FDR, false discovery rate; GO, Gene Ontology; mAb, monoclonal antibody; pAb, polyclonal antibody; qRT-PCR, quantitative RT-PCR; SAM, Significance Analysis of Microarrays; shRNA, short hairpin RNA; siRNA, small interfering RNA; VGP, vertical growth phase

\section{REFERENCES}

1. Villanueva J, Herlyn M. Melanoma. In: Encyclopedia of Life Sciences (ELS). John Wiley \& Sons, Ltd, Chichester. 2009.

2. Flaherty KT, Hodi FS, Fisher DE. From genes to drugs: targeted strategies for melanoma. Nat Rev Cancer. 2012; 12: 349-361.

3. Horn S, Figl A, Rachakonda PS, Fischer C, Sucker A, Gast A, Kadel S, Moll I, Nagore E, Hemminki K, Schadendorf D, Kumar R. TERT promoter mutations in familial and sporadic melanoma. Science. 2013; 339: 959-961.

4. Huang FW, Hodis E, Xu MJ, Kryukov GV, Chin L, Garraway LA. Highly recurrent TERT promoter mutations in human melanoma. Science. 2013; 339: 957-959.

5. Breslow A. Thickness, cross-sectional areas and depth of invasion in the prognosis of cutaneous melanoma. Ann Surg. 1970; 172: 902-908.

6. Balch CM, Gershenwald JE, Soong SJ, Thompson JF, Atkins MB, Byrd DR, Buzaid AC, Cochran AJ, Coit DG, Ding S, Eggermont AM, Flaherty KT, Gimotty PA, et al. Final version of 2009 AJCC melanoma staging and classification. J Clin Oncol. 2009; 27: 6199-6206.

7. Murali R, Haydu LE, Quinn MJ, Saw RP, Shannon K, Spillane AJ, Stretch JR, Thompson JF, Scolyer RA. Sentinel lymph node biopsy in patients with thin primary cutaneous melanoma. Ann Surg. 2012; 255: 128-133.

8. van Akkooi AC, Verhoef C, Eggermont AM. Importance of tumor load in the sentinel node in melanoma: clinical dilemmas. Nat Rev Clin Oncol. 2010; 7: 446-454.

9. Eggermont AM, Spatz A, Robert C. Cutaneous melanoma. Lancet. 2014; 383: 816-827.

10. Mustafa D, van der Weiden M, Zheng P, Nigg A, Luider TM, Kros JM. Expression sites of colligin 2 in glioma blood vessels. Brain Pathol. 2010; 20: 50-65.

11. Astorgues-Xerri L, Riveiro ME, Tijeras-Raballand A, Serova M, Neuzillet C, Albert S, Raymond E, Faivre S. Unraveling galectin-1 as a novel therapeutic target for cancer. Cancer Treat Rev. 2014; 40: 307-319.

12. Hur K, Han TS, Jung EJ, Yu J, Lee HJ, Kim WH, Goel A, Yang HK. Up-regulated expression of sulfatases (SULF1 and SULF2) as prognostic and metastasis predictive markers in human gastric cancer. J Pathol. 2012; 228: 88-98.

13. Chen SY, Lin JS, Yang BC. Modulation of tumor cell stiffness and migration by type IV collagen through direct activation of integrin signaling pathway. Arch Biochem Biophys. 2014; 555-556: 1-8.
14. Schubert K, Gutknecht D, Koberle M, Anderegg U, Saalbach A. Melanoma cells use Thy-1 (CD90) on endothelial cells for metastasis formation. Am J Pathol. 2013; 182: 266-276.

15. Lee KW, Sung CO, Kim JH, Kang M, Yoo HY, Kim HH, $\mathrm{Um} \mathrm{SH}$, Kim SH. CD10 expression is enhanced by Twist 1 and associated with poor prognosis in esophageal squamous cell carcinoma with facilitating tumorigenicity in vitro and in vivo. Int J Cancer. 2015; 136: 310-321.

16. Canesin G, Cuevas EP, Santos V, Lopez-Menendez C, Moreno-Bueno G, Huang Y, Csiszar K, Portillo F, Peinado H, Lyden D, Cano A. Lysyl oxidase-like 2 (LOXL2) and E47 EMT factor: novel partners in E-cadherin repression and early metastasis colonization. Oncogene. 2014; 34: 951-964.

17. Nyren-Erickson EK, Jones JM, Srivastava DK, Mallik S. A disintegrin and metalloproteinase-12 (ADAM12): function, roles in disease progression, and clinical implications. Biochim Biophys Acta. 2013; 1830: 4445-4455.

18. Semenza GL. Defining the role of hypoxia-inducible factor 1 in cancer biology and therapeutics. Oncogene. 2010; 29: 625-634.

19. Gilkes DM, Semenza GL, Wirtz D. Hypoxia and the extracellular matrix: drivers of tumour metastasis. Nat Rev Cancer. 2014; 14: 430-439.

20. Pyagay P, Heroult M, Wang Q, Lehnert W, Belden J, Liaw L, Friesel RE, Lindner V. Collagen triple helix repeat containing 1 , a novel secreted protein in injured and diseased arteries, inhibits collagen expression and promotes cell migration. Circ Res. 2005; 96: 261-268.

21. Park EH, Kim S, Jo JY, Kim SJ, Hwang Y, Kim JM, Song SY, Lee DK, Koh SS. Collagen triple helix repeat containing-1 promotes pancreatic cancer progression by regulating migration and adhesion of tumor cells. Carcinogenesis. 2013; 34: 694-702.

22. Perotti V, Baldassari P, Bersani I, Molla A, Vegetti C, Tassi E, Dal Col J, Dolcetti R, Anichini A, Mortarini R. NFATc2 is a potential therapeutic target in human melanoma. J Invest Dermatol. 2012; 132: 2652-2660.

23. LeClair RJ, Durmus T, Wang Q, Pyagay P, Terzic A, Lindner V. Cthrc1 is a novel inhibitor of transforming growth factor-beta signaling and neointimal lesion formation. Circ Res. 2007; 100: 826-833.

24. Flockhart RJ, Armstrong JL, Reynolds NJ, Lovat PE. NFAT signalling is a novel target of oncogenic BRAF in metastatic melanoma. Br J Cancer. 2009; 101: 1448-1455.

25. Miller VL, Lin HK, Murugan P, Fan M, Penning TM, Brame LS, Yang Q, Fung KM. Aldo-keto reductase family 1 member C3 (AKR1C3) is expressed in adenocarcinoma and squamous cell carcinoma but not small cell carcinoma. Int J Clin Exp Pathol. 2012; 5: 278-289.

26. Tian Y, Zhao L, Zhang H, Liu X, Zhao L, Zhao X, Li Y, Li J. AKR1C3 overexpression may serve as a promising biomarker for prostate cancer progression. Diagn Pathol. 2014; 9: 42. 
27. Mantel A, Carpenter-Mendini A, VanBuskirk J, Pentland AP. Aldo-keto Reductase 1C3 (AKR1C3) is overexpressed in skin squamous cell carcinoma (SCC) and affects SCC growth via prostaglandin metabolism. Exp Dermatol. 2014; 23: 573-578.

28. Wu CH, Ko JL, Chen SC, Lin YW, Han CP, Yang TY, Chien $\mathrm{MH}$, Wang PH. Clinical implications of aldo-keto reductase family 1 member $\mathrm{C} 3$ and its relationship with lipocalin 2 in cancer of the uterine cervix. Gynecol Oncol. 2014; 132: 474-482.

29. De Rosa A, Pellegatta S, Rossi M, Tunici P, Magnoni L, Speranza MC, Malusa F, Miragliotta V, Mori E, Finocchiaro G, Bakker A. A radial glia gene marker, fatty acid binding protein 7 (FABP7), is involved in proliferation and invasion of glioblastoma cells. PLoS One. 2012; 7: e52113.

30. Mita R, Beaulieu MJ, Field C, Godbout R. Brain fatty acid-binding protein and omega-3/omega- 6 fatty acids: mechanistic insight into malignant glioma cell migration. J Biol Chem. 2010; 285: 37005-37015.

31. Bravo-Cordero JJ, Magalhaes MA, Eddy RJ, Hodgson L, Condeelis J. Functions of cofilin in cell locomotion and invasion. Nat Rev Mol Cell Biol. 2013; 14: 405-415.

32. Weide B, Richter S, Buttner P, Leiter U, Forschner A, Bauer J, Held L, Eigentler TK, Meier F, Garbe C. Serum S100B, lactate dehydrogenase and brain metastasis are prognostic factors in patients with distant melanoma metastasis and systemic therapy. PLoS One. 2013; 8: e81624.

33. Kruijff S, Hoekstra HJ. The current status of S-100B as a biomarker in melanoma. Eur J Surg Oncol. 2012; 38: 281-285.

34. Kääriäinen E, Nummela $P$, Soikkeli J, Yin M, Lukk M, Jahkola T, Virolainen S, Ora A, Ukkonen E, Saksela O, Hölttä E. Switch to an invasive growth phase in melanoma is associated with tenascin- $\mathrm{C}$, fibronectin, and procollagen-I forming specific channel structures for invasion. J Pathol. 2006; 210: 181-191.

35. Soikkeli J, Podlasz P, Yin M, Nummela P, Jahkola T, Virolainen S, Krogerus L, Heikkilä P, von Smitten K, Saksela O, Hölttä E. Metastatic outgrowth encompasses COL-I, FN1, and POSTN up-regulation and assembly to fibrillar networks regulating cell adhesion, migration, and growth. Am J Pathol. 2010; 177: 387-403.

36. Gilkes DM, Chaturvedi P, Bajpai S, Wong CC, Wei H, Pitcairn S, Hubbi ME, Wirtz D, Semenza GL. Collagen prolyl hydroxylases are essential for breast cancer metastasis. Cancer Res. 2013; 73: 3285-3296.

37. Gebhardt C, Nemeth J, Angel P, Hess J. S100A8 and S100A9 in inflammation and cancer. Biochem Pharmacol. 2006; 72: 1622-1631.

38. Scala S, Ottaiano A, Ascierto PA, Cavalli M, Simeone E, Giuliano P, Napolitano M, Franco R, Botti G, Castello G. Expression of CXCR4 predicts poor prognosis in patients with malignant melanoma. Clin Cancer Res. 2005; 11: 1835-1841.

39. Teicher BA, Fricker SP. CXCL12 (SDF-1)/CXCR4 pathway in cancer. Clin Cancer Res. 2010; 16: 2927-2931.
40. Jiang L, Lv X, Li J, Li J, Li X, Li W, Li Y. The status of microRNA-21 expression and its clinical significance in human cutaneous malignant melanoma. Acta Histochem. 2012; 114: 582-588.

41. Song T, Dou C, Jia Y, Tu K, Zheng X. TIMP-1 activated carcinoma-associated fibroblasts inhibit tumor apoptosis by activating SDF1/CXCR4 signaling in hepatocellular carcinoma. Oncotarget. 2015; 6: 12061-12079. doi: 10.18632/ oncotarget.3616.

42. Cui H, Seubert B, Stahl E, Dietz H, Reuning U, MorenoLeon L, Ilie M, Hofman P, Nagase H, Mari B, Kruger A. Tissue inhibitor of metalloproteinases-1 induces a protumourigenic increase of miR-210 in lung adenocarcinoma cells and their exosomes. Oncogene. 2015; 34:3640-50. doi: 10.1038/onc.2014.300.

43. Wang K, Wang B, Xing AY, Xu KS, Li GX, Yu ZH. Prognostic significance of SERPINE2 in gastric cancer and its biological function in SGC7901 cells. J Cancer Res Clin Oncol. 2015; 141: 805-812.

44. Wagenblast E, Soto M, Gutierrez-Angel S, Hartl CA, Gable AL, Maceli AR, Erard N, Williams AM, Kim SY, Dickopf S, Harrell JC, Smith AD, Perou CM, et al. A model of breast cancer heterogeneity reveals vascular mimicry as a driver of metastasis. Nature. 2015; 520: 358-362.

45. Cheon DJ, Tong Y, Sim MS, Dering J, Berel D, Cui X, Lester J, Beach JA, Tighiouart M, Walts AE, Karlan BY, Orsulic S. A collagen-remodeling gene signature regulated by TGF-beta signaling is associated with metastasis and poor survival in serous ovarian cancer. Clin Cancer Res. 2014; 20: 711-723.

46. Soikkeli J, Lukk M, Nummela P, Virolainen S, Jahkola T, Katainen R, Harju L, Ukkonen E, Saksela O, Hölttä E. Systematic search for the best gene expression markers for melanoma micrometastasis detection. J Pathol. 2007; 213: 180-189.

47. Ignotz RA, Endo T, Massague J. Regulation of fibronectin and type I collagen mRNA levels by transforming growth factor-beta. J Biol Chem. 1987; 262: 6443-6446.

48. Fernandez-Zapico ME, Ellenrieder V. NFAT transcription factors, the potion mediating 'Dr. Jekill-Mr. Hyde' transformation of the TGFbeta pathway in cancer cells. Cell Cycle. 2010; 9: 3838-3839.

49. Platten M, Wick W, Wild-Bode C, Aulwurm S, Dichgans J, Weller M. Transforming growth factors beta(1) (TGFbeta(1)) and TGF-beta(2) promote glioma cell migration via Up-regulation of alpha(V)beta(3) integrin expression. Biochem Biophys Res Commun. 2000; 268: 607-611.

50. Faralli JA, Gagen D, Filla MS, Crotti TN, Peters DM. Dexamethasone increases alphavbeta3 integrin expression and affinity through a calcineurin/NFAT pathway. Biochim Biophys Acta. 2013; 1833: 3306-3313.

51. Albelda SM, Mette SA, Elder DE, Stewart R, Damjanovich L, Herlyn M, Buck CA. Integrin distribution in malignant melanoma: association of the beta 3 subunit with tumor progression. Cancer Res. 1990; 50: 6757-6764. 
52. Hsu MY, Shih DT, Meier FE, Van Belle P, Hsu JY, Elder DE, Buck CA, Herlyn M. Adenoviral gene transfer of beta3 integrin subunit induces conversion from radial to vertical growth phase in primary human melanoma. Am J Pathol. 1998; 153: 1435-1442.

53. Ross FP, Chappel J, Alvarez JI, Sander D, Butler WT, Farach-Carson MC, Mintz KA, Robey PG, Teitelbaum SL, Cheresh DA. Interactions between the bone matrix proteins osteopontin and bone sialoprotein and the osteoclast integrin alpha $\mathrm{v}$ beta 3 potentiate bone resorption. J Biol Chem. 1993; 268: 9901-9907.

54. Lawler J, Weinstein R, Hynes RO. Cell attachment to thrombospondin: the role of ARG-GLY-ASP, calcium, and integrin receptors. J Cell Biol. 1988; 107: 2351-2361.

55. Charo IF, Nannizzi L, Smith JW, Cheresh DA. The vitronectin receptor alpha $\mathrm{v}$ beta 3 binds fibronectin and acts in concert with alpha 5 beta 1 in promoting cellular attachment and spreading on fibronectin. J Cell Biol. 1990; 111: 2795-2800.

56. Yin M, Soikkeli J, Jahkola T, Virolainen S, Saksela O, Hölttä E. Osteopontin promotes the invasive growth of melanoma cells by activating integrin alphavbeta3 and down-regulating tetraspanin CD9. Am J Pathol. 2014; 184: 842-858.

57. Tanabe N, Wheal BD, Kwon J, Chen HH, Shugg RP, Sims SM, Goldberg HA, Dixon SJ. Osteopontin signals through calcium and nuclear factor of activated T cells (NFAT) in osteoclasts: a novel RGD-dependent pathway promoting cell survival. J Biol Chem. 2011; 286: 39871-39881.

58. Wang P, Wang YC, Chen XY, Shen ZY, Cao H, Zhang YJ, Yu J, Zhu JD, Lu YY, Fang JY. CTHRC1 is upregulated by promoter demethylation and transforming growth factorbetal and may be associated with metastasis in human gastric cancer. Cancer Sci. 2012; 103: 1327-1333.

59. Chen YL, Wang TH, Hsu HC, Yuan RH, Jeng YM. Overexpression of CTHRC1 in hepatocellular carcinoma promotes tumor invasion and predicts poor prognosis. PLoS One. 2013; 8: e70324.

60. Kharaishvili G, Cizkova M, Bouchalova K, Mgebrishvili G, Kolar Z, Bouchal J. Collagen triple helix repeat containing 1 protein, periostin and versican in primary and metastatic breast cancer: an immunohistochemical study. J Clin Pathol. 2011; 64: 977-982.

61. Ke Z, He W, Lai Y, Guo X, Chen S, Li S, Wang Y, Wang L. Overexpression of collagen triple helix repeat containing 1 (CTHRC1) is associated with tumour aggressiveness and poor prognosis in human non-small cell lung cancer. Oncotarget. 2014; 5: 9410-9424. doi: 10.18632/oncotarget.2421.

62. Tang L, Dai DL, Su M, Martinka M, Li G, Zhou Y. Aberrant expression of collagen triple helix repeat containing 1 in human solid cancers. Clin Cancer Res. 2006; 12: 3716-3722.
63. Kim JH, Baek TH, Yim HS, Kim KH, Jeong SH, Kang HB, Oh SS, Lee HG, Kim JW, Kim KD. Collagen triple helix repeat containing-1 (CTHRC1) expression in invasive ductal carcinoma of the breast: the impact on prognosis and correlation to clinicopathologic features. Pathol Oncol Res. 2013; 19: 731-737.

64. Allinen M, Beroukhim R, Cai L, Brennan C, LahtiDomenici J, Huang $\mathrm{H}$, Porter $\mathrm{D}, \mathrm{Hu} \mathrm{M}$, Chin L, Richardson A, Schnitt S, Sellers WR, Polyak K. Molecular characterization of the tumor microenvironment in breast cancer. Cancer Cell. 2004; 6: 17-32.

65. West RB, Nuyten DS, Subramanian S, Nielsen TO, Corless CL, Rubin BP, Montgomery K, Zhu S, Patel R, HernandezBoussard T, Goldblum JR, Brown PO, van de Vijver $\mathrm{M}$, et al. Determination of stromal signatures in breast carcinoma. PLoS Biol. 2005; 3: e187.

66. Yin M, Soikkeli J, Jahkola T, Virolainen S, Saksela O, Holtta E. TGF-beta signaling, activated stromal fibroblasts, and cysteine cathepsins $\mathrm{B}$ and $\mathrm{L}$ drive the invasive growth of human melanoma cells. Am J Pathol. 2012; 181: 2202-2216.

67. Mahabeleshwar GH, Feng W, Phillips DR, Byzova TV. Integrin signaling is critical for pathological angiogenesis. J Exp Med. 2006; 203: 2495-2507.

68. Mahabeleshwar GH, Feng W, Reddy K, Plow EF, Byzova TV. Mechanisms of integrin-vascular endothelial growth factor receptor cross-activation in angiogenesis. Circ Res. 2007; 101: 570-580.

69. Hernandez GL, Volpert OV, Iniguez MA, Lorenzo E, Martinez-Martinez S, Grau R, Fresno M, Redondo JM. Selective inhibition of vascular endothelial growth factor-mediated angiogenesis by cyclosporin A: roles of the nuclear factor of activated $\mathrm{T}$ cells and cyclooxygenase 2. J Exp Med. 2001; 193: 607-620.

70. Astrof S, Hynes RO. Fibronectins in vascular morphogenesis. Angiogenesis. 2009; 12: 165-175.

71. Rybak JN, Roesli C, Kaspar M, Villa A, Neri D. The extradomain A of fibronectin is a vascular marker of solid tumors and metastases. Cancer Res. 2007; 67: 10948-10957.

72. Castellani P, Viale G, Dorcaratto A, Nicolo G, Kaczmarek J, Querze G, Zardi L. The fibronectin isoform containing the ED-B oncofetal domain: a marker of angiogenesis. Int $\mathrm{J}$ Cancer. 1994; 59: 612-618.

73. Bielenberg DR, Pettaway CA, Takashima S, Klagsbrun M. Neuropilins in neoplasms: expression, regulation, and function. Exp Cell Res. 2006; 312: 584-593.

74. Glinka Y, Stoilova S, Mohammed N, Prud'homme GJ. Neuropilin-1 exerts co-receptor function for TGF-beta-1 on the membrane of cancer cells and enhances responses to both latent and active TGF-beta. Carcinogenesis. 2011; 32: 613-621.

75. Stine MJ, Wang CJ, Moriarty WF, Ryu B, Cheong R, Westra WH, Levchenko A, Alani RM. Integration of genotypic and phenotypic screening reveals molecular 
mediators of melanoma-stromal interaction. Cancer Res. 2011; 71: 2433-2444.

76. Yamamoto S, Nishimura O, Misaki K, Nishita M, Minami Y, Yonemura S, Tarui H, Sasaki H. Cthrc1 selectively activates the planar cell polarity pathway of Wnt signaling by stabilizing the Wnt-receptor complex. Dev Cell. 2008; 15: 23-36.

77. Jonsson M, Smith K, Harris AL. Regulation of Wnt5a expression in human mammary cells by protein kinase $\mathrm{C}$ activity and the cytoskeleton. Br J Cancer. 1998; 78: 430-438.

78. Saneyoshi T, Kume S, Amasaki Y, Mikoshiba K. The Wnt/ calcium pathway activates NF-AT and promotes ventral cell fate in Xenopus embryos. Nature. 2002; 417: 295-299.

79. Griesmann H, Ripka S, Pralle M, Ellenrieder V, Baumgart S, Buchholz M, Pilarsky C, Aust D, Gress TM, Michl P. WNT5A-NFAT signaling mediates resistance to apoptosis in pancreatic cancer. Neoplasia. 2013; 15: 11-22.

80. Wang Y, Shibasaki F, Mizuno K. Calcium signal-induced cofilin dephosphorylation is mediated by Slingshot via calcineurin. J Biol Chem. 2005; 280: 12683-12689.

81. Matus DQ, Lohmer LL, Kelley LC, Schindler AJ, Kohrman AQ, Barkoulas M, Zhang W, Chi Q, Sherwood DR. Invasive Cell Fate Requires G1 Cell-Cycle Arrest and Histone Deacetylase-Mediated Changes in Gene Expression. Dev Cell. 2015; 35: 162-174.

82. Gil-Henn H, Patsialou A, Wang Y, Warren MS, Condeelis JS, Koleske AJ. Arg/Abl2 promotes invasion and attenuates proliferation of breast cancer in vivo. Oncogene. 2013; 32: 2622-2630.

83. Hou M, Cheng Z, Shen H, He S, Li Y, Pan Y, Feng C, Chen X, Zhang Y, Lin M, Wang L, Ke Z. High expression of CTHRC1 promotes EMT of epithelial ovarian cancer (EOC) and is associated with poor prognosis. Oncotarget. 2015; 6: 35813-35829. doi: 10.18632/oncotarget.5358.

84. Calon A, Lonardo E, Berenguer-Llergo A, Espinet E, Hernando-Momblona X, Iglesias M, Sevillano M, PalomoPonce S, Tauriello DV, Byrom D, Cortina C, Morral C, Barcelo $\mathrm{C}$, et al. Stromal gene expression defines poor-prognosis subtypes in colorectal cancer. Nat Genet. 2015; 47: 320-329.

85. Miles FL, Sikes RA. Insidious changes in stromal matrix fuel cancer progression. Mol Cancer Res. 2014; 12: 297-312.
86. Liu JF, Zhao SH, Wu SS. Depleting NFAT1 expression inhibits the ability of invasion and migration of human lung cancer cells. Cancer Cell Int. 2013; 13: 41.

87. Mancini M, Toker A. NFAT proteins: emerging roles in cancer progression. Nat Rev Cancer. 2009; 9: 810-820.

88. Medyouf H, Ghysdael J. The calcineurin/NFAT signaling pathway: a novel therapeutic target in leukemia and solid tumors. Cell Cycle. 2008; 7: 297-303.

89. Pickup M, Novitskiy S, Moses HL. The roles of TGFbeta in the tumour microenvironment. Nat Rev Cancer. 2013; 13: 788-799.

90. Singh G, Singh SK, Konig A, Reutlinger K, Nye MD, Adhikary T, Eilers M, Gress TM, Fernandez-Zapico ME, Ellenrieder V. Sequential activation of NFAT and c-Myc transcription factors mediates the TGF-beta switch from a suppressor to a promoter of cancer cell proliferation. J Biol Chem. 2010; 285: 27241-27250.

91. Sengupta S, Jana S, Biswas S, Mandal PK, Bhattacharyya A. Cooperative involvement of NFAT and SnoN mediates transforming growth factor-beta (TGF-beta) induced EMT in metastatic breast cancer (MDA-MB 231) cells. Clin Exp Metastasis. 2013; 30: 1019-1031.

92. Tusher VG, Tibshirani R, Chu G. Significance analysis of microarrays applied to the ionizing radiation response. Proc Natl Acad Sci U S A. 2001; 98: 5116-5121.

93. Kielosto M, Nummela P, Katainen R, Leaner V, Birrer MJ, Hölttä E. Reversible regulation of the transformed phenotype of ornithine decarboxylase- and ras-overexpressing cells by dominant-negative mutants of c-Jun. Cancer Res. 2004; 64: 3772-3779.

94. Ravanko K, Järvinen K, Helin J, Kalkkinen N, Hölttä E. Cysteine cathepsins are central contributors of invasion by cultured adenosylmethionine decarboxylase-transformed rodent fibroblasts. Cancer Res. 2004; 64: 8831-8838.

95. Nummela P, Lammi J, Soikkeli J, Saksela O, Laakkonen P, Hölttä E. Transforming growth factor beta-induced (TGFBI) is an anti-adhesive protein regulating the invasive growth of melanoma cells. Am J Pathol. 2012; 180: 1663-1674.

96. Alanko T, Rosenberg M, Saksela O. FGF expression allows nevus cells to survive in three-dimensional collagen gel under conditions that induce apoptosis in normal human melanocytes. J Invest Dermatol. 1999; 113: 111-116. 